\title{
Turizm İşletmeleri İçin AHP Temelli Bulanık TOPSIS Yönetimi ile Tur Operatörü Seçimi
}

\author{
Tour Operator Selection by Using AHP Based Fuzzy TOPSIS Method For \\ Tourism Businesses
}

\author{
Yrd. Doç. Dr. Meltem Karaatlı - Doç. Dr. Nuri Ömürbek \\ Esra Aksoy - Hanife Karakuzu
}

\section{Öz}

Turizm sektöründe faaliyet gösteren işletmeler, bu sektörde rakipleri ile mücadele edebilmek için hizmet kalitelerini sürekli en üst noktada tutmak zorundadirlar. Turizm sektöründe oldukça önemli bir paya sahip olan otel işletmeleri yüksek kalite anlayışı ve müşteri odaklı politikalara bağlı kalarak rekabet avantajı elde edebilirler. Bunun içinde otel işletmeleri çalışacağı tur operatörünü belirlerken birtakım kriterleri göz önünde bulundurmalidir. Bu nedenle de tur operatörlerinin hangi kriterlere ve hangi ağırlıklara göre saptanacağının belirlenmesi çok kriterli karar verme sürecinin değerlendirilmesinde belirleyici öneme sahiptir. Bu çalısmada da Isparta ilinde faaliyet gösteren beşyıldızlı bir otelin tur operatörü seçiminde göz önüne aldiğı kriterlerin ă̆ırlik dereceleri Analitik Hiyerarşi Süreci (AHP - Analytic Hierarchy Process) ile belirlenmiştir. Elde edilen ağırlıklar çok kriterli karar verme tekniklerinden Bulanik TOPSIS (Technique For Order Preference By Similarity To An Ideal Solution) yönteminde kullanılarak tur operatörleri değerlendirilmiş ve otel için en iyi tur operatörü tespit edilmiştir.

Anahtar Kelimeler: Çok Kriterli Karar Verme, AHP, Bulanık TOPSIS, Tur Operatörleri, Turizm İşletmeleri

\begin{abstract}
Businesses operating in the tourism industry constantly obliged to keep the top spot of their quality of service to be able to fight with other competitors. Hotels in the tourism sector with a significant share can achieve a competitive advantage with adhering to customer-oriented policies and high quality service. For this reason, hotels should consider some criteria when deciding the tour operator. Therefore, determination of tour operators selected in according to what criteria and what weights has decisive importance in the evaluation of a multi-criteria decision-making-process. In this study, the severity of criteria when choosing the tour operator which are taken into account by a five-star hotel in Isparta was determined by AHP (Analytic Hierarchy Process). The weights obtained by AHP were used in Fuzzy TOPSIS (Technique For Order Preference By Similarity To An Ideal Solution) which is one of the multi-criteria decision making techniques to evaluate tour operators. Finally, the best tour operator for the hotel was identified.
\end{abstract}

Keywords: Multi Criteria Decision Making, AHP, Fuzzy TOPSIS, Tour Operator, Tourism Businesses

Yrd. Doç. Dr. Meltem Karaatlı, Süleyman Demirel Üniversitesi İİBF İşletme Bölümü, meltemkaraatli@sdu.edu.tr Doç. Dr. Nuri Ömürbek, Süleyman Demirel Üniversitesi İİBF İșletme Bölümü, nuriomurbek@sdu.edu.tr Esra Aksoy, Süleyman Demirel Üniversitesi İİBF İşletme Bölümü, esraksy@hotmail.com Hanife Karakuzu, Süleyman Demirel Üniversitesi İİB İşletme Bölümü, krkz_hanife@hotmail.com 


\section{Giriş}

Turizm sektörü geçmişten günümüze hem gelişmiş hem de gelişmekte olan ülkeler tarafından yoğun şekilde ilgi gösterilen bir sektör olma özelliğindedir. Bunun en önemli sebebi ise, dünya genelinde diğer sektörlerden, daha hızlı gelişen bir sektör olmasıdır. Aynı zamanda bu durum, turizm sektörünün ülke ekonomilerine katkılarını da ön plana çıkararak ilgiyi daha da üstüne çekmesini sağlamaktadır. Turizm sektörü, küresel düzeyde hızla değişen pazar ve rekabet koşulları sebebiyle sürekli ve dinamik bir gelişim süreci içindedir.(Yıldız, 2011, s.54)

Turizm işletmeleri; geçici bir zaman dilimi için yer değiştirme hareketinin doğurduğu seyahat ve konaklama ihtiyaçlarının ve buna bağlı diğer ihtiyaçların karşılanmasına yarayan mal ve hizmetlerin üretilmesini ve pazarlanmasını sağlayan ekonomik birimler olarak tanımlanabilmektedir. Turizm işletmeleri; turistlerin temel ihtiyaçlarının karşılanması dikkate alınarak; seyahat işletmeleri, konaklama işletmeleri, ulaştırma işletmeleri, yiyecek- içecek işletmeleri, rekreasyon (eğlence- dinlence) işletmeleri ve alışveriş işletmeleri şeklinde sınıflandırılabilir.(Meb, 2007a, s.5)

Günümüzde seyahat işletmeciliği ile ilgili çalışmaları koordine eden ve hazırlayan iki çeşit işletme vardir. Bunlar ; seyahat acenteleri ve tur operatörleridir. (Gökdeniz, 1990, s.44) Seyahat acentaları seyahat etmek isteyen kişilerin seyahate ilişkin tüm ihtiyaçlarını karşılayan ticari kuruluşlarken (Emir, 2010, s.1248), tur operatörleri, önceden herhangi bir talep olmadan paket turlar hazırlayan, turistlerin yönelimlerini belirleyen ve belirli bir destinasyonu turistik ürün olarak pazarlayan seyahat işletmeleridir. (Alaeddinoğlu ve Can, 2007, s.51)

Bir seyahatin ayrı ayrı parçalarının (ulaştırma, konaklama, yeme-içme, eğlence gibi) birleştirilerek müşteriye tek bir ürün ve fiyat olarak satılmasını içeren ve kitle turizmine konu olan paket turların hazırlanması, seyahatle ilgili çalışmaların organizasyonu ve turistik ürün oluşturulması, seyahat işletmeleri adı altında tur operatörleri gerçekleştirmektedir. (Gökdeniz, 1990, s.44)

Turizm işletmeleriyle anlaşma yaparak, seyahat ile ilgili bütün hizmetlerin bir araya getirildiği organize turları, seyahat acenteleri ile pazarlayan tur operatörleri, bir tatil esnasinda yararlanılabilecek olası hizmetlerin toplamından turistik ürün oluşturmakta ve bu ürünü belirli bir fiyatı kapsayacak şekilde doğrudan veya seyahat acenteleri aracıllğıyla tüketicilerin kullanımına sunmaktadırlar. Bir paket tur için ödenen fiyat, tatil bileşenlerinin ayrı ayrı satın alınması durumunda ödenebilecek fiyattan çok daha ucuz olduğu için ur operatörü tarafından bir araya getirilerek oluşturulan paket turu satın almak tüketicilerin lehine olmaktadır. Tur operatörleri tüketicilere güvenli, rahat ve nispeten ucuz bir tatil olanağı sunmakta ve üretilen seyahat paketleri ile günümüz toplumunun iki ayırıcı özelliği olan artan stres ve daha az boş vakti bertaraf ederek zamandan kazanım sağlamaktadır. Ayrıca tur operatörleri kendi personeli ve seyahat acenteleri personeli için yaptığı eğitim seyahatleri ile reklamlar ve tanitımları destekleyerek turizm sezonunun bütün yıla yayılmasına destek olmaktadırlar. (Alaeddinoğlu ve Can, 2007, s.53)

Konaklama işletmeleri kapsamındaki otel işletmeciliği tur operatörleri ile her zaman yakın ilişki içindedir. Konaklama işletmeleri, kendilerini tur operatörlerine tanıtmak zorundadır ve konaklama işletmeleri tur operatörleriyle çalışmak isterlerse, tur operatörleri ile en az bir yıl öncesinden temaslara geçmektedirler. (MEB, 2007b, s.30) Turizm işletmelerinde son zamanlarda uygulanan her şey dahil sisteminin iki farklı düzeyde uygulamasıyla karşılaşılabilinmektedir. Bunlardan birincisi; tur operatörleri tarafindan önerilmekte olan her şey dahil seyahatler, diğeri ise, yine her şey dahil seyahatlerin türevi olarak yorumlanabilecek her şey dahil konaklamalardır. Tur operatörlerince tüketiciler tarafından algılanmakta olan satın alma riskini düşürmek amaçlı olarak geliştirilen her şey dahil seyahat ürünün, dağıtım kanalının bir sonraki aşamasında yer alan konaklama işletmelerine de yansitılması gerekir. Yani, tur operatörleri tarafından geliştirilen sistemin konaklama işletmeleri bir nevi otel işletmeleri tarafindan da benimsenmesi ve uygulanması gerekir. (Üner vd., 2006, s.36)

Her bir tur operatörünün kendine özgü kurumsal özellikleri ve üstünlükleri bulunmaktadır. Turizm işletmeleri için de tur operatörü seçimi oldukça önemli bir konudur. Bu bağlamda turizm işletmeleri için tur operatörü seçimi çok kriterli karar bir karar vermeyi gerektirmektedir.

Çok kriterli karar verme birçok kriteri birlikte değerlendirerek alternatiflere değerler atama süreci demektir. Çok kriterli karar verme yaklaşımları; çok nitelikli karar verme ve çok amaçlı karar verme ol- 
mak üzere ikiye ayrılmaktadır. Eğer problem bir takım özelliklere puanlar vererek alternatiflerin değerlendirilmesi ve en iyisinin seçilmesi esasına dayalı ise bu tip problemlere çok nitelikli karar verme problemi denmektedir. Çok amaçlı karar verme problemi ise çelişen amaçlara dayalı en iyi alternatifin seçimi ile ilgilidir. Her iki problem tipinde de bir ya da birden fazla karar verici vardır. Bu çalışmada da çok nitelikli karar verme problemi ele alınmıştır. (Phua ve Minowa, 2005, s.208)

\section{Literatür Özeti}

\section{AHP Yöntemi ile yapılan çalışmalar:}

Çok kriterli karar verme yöntemlerinden biri olan AHP son yirmibeş yll içinde otuzdan fazla farkl alanda uygulanmıştır. (Chandran vd., 2005, s.2235) AHP yöntemi en uygun tedarikçi seçimi, işletmelerin kuruluş yeri belirlemelerinde, pazarlama alanında, yönetim kararlarının alınmasında, turizm sektöründe, müşteri bağımlılığında, hastanelerde tıbbı malzeme alımıyla ilgili kararlarda, bilgisayar seçimlerinde, strateji belirlemede, politikaların değerlendirilmesinde ve daha birçok alanda uygulanmaktadır

Christian B.Alphonce çalışmasında; nitel yargıların kullanımında çeşitli yaklaşımların geliştiğini ve bu yaklaşımlardan biri olan çok kriterli karar verme yöntemlerine olan ilginin artmaya başladığı sonucunu ortaya koymuştur. Bu yöntemlerden biri olan AHP yöntemi de birkaç istisna dışında çeşitli alanlardaki sorunlara çözümler getirmiştir. Bu yöntem, gelişmekte olan ülkelerdeki tarım alanlarında uygulama alanı bulamamıştır. Bu çalışma, AHP metoduna yeni bir uygulama alanı katmıştır ve gelişmekte olan ülkelerde tarım alanlarından elde edilen karlara ait bir uygulama önerisidir. (Alphonce, 1997, s.97-112)

Ahti A.Salo ve Raimo P.Hamalainen çalışmalarında; çok kriterli karar verme yöntemlerinden AHP yönteminde ikili karşılaştırma yapıları incelemişlerdir. Çalışmada bir yandan AHP yönteminde yapılan analizlerde ikili karşılaştırma çiftleri arasındaki tercih farklılıkları ya da alternatifler açısından farklılıklar belirlenirken diğer yandan da verilen herhangi bir oran ölçeğinin üst sınırının ve farklılığının neden olduğu etkiler belirtilmiştir. Ayrıca AHP yönteminin çok nitelikli değer alan ölçümlere benzer sonuçlar ortaya koyduğu da kanıtlanmaktadır. (Salo ve Hamalainen 1997, s.309-319)
Bevilacquaa ve Bragliab çalışmalarında, AHP yöntemi ile büyük bir İtalyan yağ rafinerisindeki en iyi bakım stratejisinin belirlenmesine çalışmışlardır. Makineler yağ fabrikasındaki iç prosedürün kritiklik durumuna bağlı olarak 3 homojen gruba ayrılmıştır. AHP yöntemi ile bakım stratejisi yöntemlerinde adı geçen her karakteristik özellik ikili karşılaştırmalar yapılarak değerlendirilmiştir. (Bevilacquaa ve Bragliab, 1999, s.71-83)

Kuruüzüm ve Atsan; Analitik Hiyerarşi Yöntemi konusunda yapılacak çalışmalara katkı sağlamak amacıyla yöntemin kavramsal temeli, analitik süreci ve işletmecilik alanındaki uygulamalarına yönelik bir çalışma yapmışlardır. Örnek uygulamalarında ise Akdeniz Üniversitesinin iş idaresi yüksek lisans programını yeni bitirmiş bir mezun öğrenciye Ankara, İstanbul, İzmir ve Antalya şehirlerinden gelen aynı niteliklere sahip iş tekliflerini nasıl değerlendireceği sorununu ele almışlardır. Mezun öğrencinin kararını etkiyecek kriterler; ailesinin bulunduğu șehre olan uzaklık, yaşam maliyeti, iklim koşulları, eğitim olanakları ve yaşam kalitesi olarak belirlenmiştir. İkili karşılaştırma matrisleri oluşturarak problemi AHP yöntemiyle ele almışlardır. Sonuç olarak öğrencinin yaşamak için en büyük önceliğe sahip olan İstanbul ilini seçmesi gerektiği uygun görülmüştür. (Kuruüzüm ve Atsan, 2001, s.83-105)

Hwang, Moon, Chuang ve Goan, AHP yöntemi ile tedarikçi seçimi ve planlama modeli üzerine bir çalışma hazırlamışlardır. Tedarikçi seçiminin değerlendirilmesi çok kriterli karar yöntemini içermektedir. AHP ile üç aşamalı bir karar analizi modeli kullanarak önerilen ilk analiz modeli nicel ölçü güvenilirliği aktarmakta ve tedarikçi için niteliksel faktörlere dönüştürülmesini sağlamaktadır. Sonrasında ise, entegrasyon modeli çoklu analizin sonuçlarını birleştirmekte ve en iyi tedarikçiyi seçmektedir. (Hwang vd., 2005, s.47-53.)

Başkaya ve Akar, bir tekstil işletmesinin ham kumaş, boyalı kumaş ve perdelik kumaş alternatifleri arasından hangisini üretmesi gerektiğine AHP yöntemi ile karar vermeye çalışmışlardır. Çalışmada karara etki eden kriter ve alt kriterler işletme sahibi ve yöneticileriyle birlikte ortak olarak; karlılık, satılabilirlik, verimlilik ve hammadde temini olarak belirlenmiş ve ikili karşılaştırmalı matris yardımıyla değerlendirilmiştir. Çalışma sonucunda işletme için en uygun üretim alternatifinin perdelik kumaş üretimi olduğu görülmüștür. (Başkaya ve Akar, 2005, s.273-286.) 
Karagül ve Özdemir, ticari bankalar açısından kaliteli finansal bilginin unsurlarının önem ağırlıklarını Analitik Hiyerarşi Süreci tekniği ile belirlenmeye çalışmışlardır. Finansal bilgi kalitesinin belirlenebilmesi amacına yönelik olarak verilerin elde edilmesinde anket formu kullanılmıştır. Uzmanlardan elde edilen yanıtlar öncelikle uzmanların dahil oldukları gruplar acısından incelenmiş ve ardından grup görüşleri birleștirilmiştir. Böylelikle grupların ayrı ayrı ve bütün olarak finansal bilgi kalitesini değerlendirme sonuçlarına ulaşılmıştır. Çalışma sonucunda finansal bilgi kalitesinin en önde gelen unsurları erişim, doğruluk, güvenlik, tutarlılık ve katma değer olarak belirlenmiştir. (Karagül ve Özdemir, 2010, s.43-58)

Maniyaa ve Bhatt yapmış oldukları çalı̧̧mada, amaçları malzeme taşımak için kullanılan otomatik güdümlü araçlardaki çoklu özellik seçiminde yeni metot geliştirme ve kullanmanın araştırılmasıdır. $\mathrm{Bu}$ çalışma M-GRA ile AHP yöntemlerini birleştirmeyi amaçlamaktadır. Belirsizlik varlığında AHP/M-GRA tekniği karar almada daha uygundur ve metot bir örnek vasıtasıyla resmedilmiştir. Çalışma AHP/MGRA tekniğinin hassas analizi ve olumlu sonucuyla devam etmektedir. Çalışmanın sonucu AHP/M-GRA tekniğinin AGV sisteminin seçimi için daha uygun olduğunun güvencesini kurmuştur. (Maniyaa ve Bhatt, 2010, s.6107-3124)

Özgüven, çalışmasında İzmir'de faaliyet gösteren 4 vakıf üniversitesinin öğrenciler tarafından tercih edilme önceliği AHP yöntemiyle belirlenmeye çalışılmıştır. Değerlendirilecek kriterler; ücretler, akademik kadro, ders sayısı, faaliyet gösterdiği yıl sayısı, kontenjanlar, taban puanlar, kültürel etkinlikler, fiziki yapı ve kampüs alanıdır. Bu kriterler doğrultusunda vakıf üniversitesi tercihinde en önemli kriterin ücret olduğu tespit edilmiş ve bu önceliğe uygun olan bir vakıf üniversitesi uygun olarak belirlenmiştir. (Özgüven, 2011, s.279-290)

\section{TOPSIS Yöntemi ile yapılan çalışmalar:}

Chen'in çalışmasında her bir kriterin ağırlığı ve her bir alternatifin puanı dilsel değişkenler yardımıyla tanımlanarak üçgen bulanık sayılarla açıklanmıştır. Çalışmada iki üçgen bulanık sayı arasındaki uzaklığ hesaplayabilmek için Vertex metodu önerilmiştir. TOPSIS kavramına göre aynı anda bulanık negatif ideal çözüm ve bulanık pozitif ideal çözümün her ikisi için uzaklıkları hesaplayarak bütün alternatiflerin sıralamasını yapabilmek için bir yakınlık katsayısı tanımlanmıştır. (Chen, 2000, s.1-9)
Bu çalışmaların akabinde birçok çalışma ortaya konulmuştur bunlardan bazıları; Shih, Shyur ve Lee uygulamalarında, yerel bir kimya şirketinde insan kaynakları bölümünde personel seçimi için TOPSIS yöntemini kullanmışlar ve çok kriterli karar vermede TOPSIS yönteminin güçlü bir yöntem olduğunu belirtmişlerdir. (Shih vd., 2007, s.801-813)

Demireli, yurt çapında yaygın olarak hizmet veren kamu bankalarının performanslarını TOPSIS yöntemiyle belirlemeye çalışmıştır. Performanslarının ölçümünde ilgili kriterlerin seçiminde, 2001-2007 yılları arası faaliyet gösteren 3 bankanın TOPSIS performans sisteminin yapisina uygun 10 adet oran seçilmiştir. Çalışmanın sonucunda yurt genelinde hizmet veren kamu sermayeli bankaların yerel ve global finansal krizlerden etkilendiğini, performans puanlarının yurtdışı verilere dayalı olarak sürekli dalgalanma gösterdiği ve sektörde göze çarpan bir iyileşmenin kaydedilmediği gözlenmiştir. (Demireli, 2010, s.101-112)

Uygurtürk ve Korkmaz, çalışmalarında, İstanbul Menkul Kıymetler Borsası’nda işlem gören 13 ana metal sanayi işletmesinin 2006-2010 dönemine ait mali tablolarını kullanarak, işletmelerin finansal performanslarını TOPSIS yöntemi ile analiz etmişlerdir. İlk önce işletmelerin finansal güçlülügünü ortaya koymak amacıyla finansal oranlar hesaplanmış ve daha sonra hesaplanan oranlar; TOPSIS yöntemi kullanılarak genel şirket performansını gösteren tek bir puana çevrilmiştir. Çalışmanın sonucunda, ana metal sanayi sektöründe faaliyette bulunan işletmelerin performans puanlarının analiz döneminde genel olarak değişkenlik gösterdiği tespit edilmiştir. (Uygurtürk ve Korkmaz, 2012, s.95-115)

Ecer, personel seçimi için bulanık TOPSIS yöntemini uygulamıştır. İlk izlenim, fiziksel görünüm, diksiyon, kibarlık, iş tecrübesi, kendine güven, güler yüzlülük, beden dilini kullanma gibi kriterler göz önünde bulundurulmuştur.(Ecer, 2006, s.377-386)

Küçük ve Ecer, tedarikçi değerlendirme problemi için bulanık TOPSIS yöntemini uygulamışlardır. Fiyat, taşıma maliyeti, ürün kalitesi, hatasız ürün miktarı, tedarikçinin kaliteyi geliştirme çabası, teslimat zamanına uyma, talep değişimine cevap verme, iletişim kurmanın kolaylığı, tedarikçinin finansal yapısı, müşterilerin tedarikçiye bakış açısı, üretim yeteneği ve kapasite, coğrafi yakınlık, sorumluluk alma, anlaşmazlıkları çözümleme, teslimat miktarına uyma, 
ürünlerin ambalajlı teslimi, teknolojik düzey olmak üzere birçok kriter dikkate alınmıștır (Küçük ve Ecer, 2007, s.45-65).

Benitez vd., otel endüstrisinde hizmet kalitesinin ölçümü için bulanık TOPSIS yöntemini uygulamışlardır. Halkla ilişkiler hizmeti, bar hizmeti, ana restoranlar/akşam yemeği, ana restoran/kahvaltı, havuz ve bahçe bölgelerinin temizliği, oda bakımı, boş zaman etkinlikleri programı, oda temizliği, resepsiyon, ana restoranlar/öğle yemeği, tabak, çatal-kaşık ve bardakların temizliği, otelin genel görünüşü gibi kriterler baz alınmıştır. (Benitez vd., 2007, s.544-555).

Boran v.d., tedarikçi seçimi için bulanık TOPSIS yöntemini uygulamışlardır. Kalite, tedarikçilerle olan yakınlık, teslim performansı ve fiyat kriterleri dikkate alınmıştır. (Boran vd., 2009, s.11363-11368).

Erginel vd., numara taşınabilirliliği sonrası Türkiye’de GSM operatör tercihlerini bulanık TOPSIS yaklaşı$\mathrm{m} ı$ ile belirlemeye çalışmışlardır. Operatör içi arama fiyatı, diğer operatörleri arama fiyatı, servis ve satı̧̧ noktalarına ulaşım kolaylı̆̆ı, şebeke kalitesi, teknolojik olanaklar, kapsama alanı, yakın çevrenin aynı operatörü kullanması, internet reklamları, tv reklamları, marka imajı, müşteri memnuniyeti, tarifeler, kampanyalar gibi kriterleri dikkate almışlardır. (Erginel vd., 2010, s.81-93)

Özçakar ve Demir, bulanık TOPSIS yöntemiyle tedarikçi seçimi yapmışlardır. Maliyet, kalite, zamanında teslimat, esneklik, güvenilirlik ve ödeme koşulları gibi kriterleri dikkate almışlardır (Özçakar ve Demir, 2011, s.25-44).

Huang ve Peng, Asya ülkelerinde turizm sektöründeki rekabet gücünü değerlendirmek için bulanık TOPSIS yöntemi uygulamışlardır. Cazibe durumu, hizmet durumu, uygun fiyat, sektördeki pozitif imajı, barış ve istikrar, kültürel bağlantılar olmak üzere 6 ana kriter ve bu kriterlerin altında onbeş alt kriter belirlemişleridir. (Huang ve Peng, 2012, s.456-465).

\section{AHP ve TOPSIS Yöntemleri ile yapılan çalışmalar:}

Yurdakul ve İpek, malzeme taşıma sistemleri seçiminin daha kolay ve doğru yapılmasına yardımcı olacak bir karar destek sistemi geliştirmişlerdir. Geliştirilen karar destek sisteminde soru yöneltme, ekonomik analiz, AHP ve TOPSIS yöntemleri kullanılmıştır. Çalışmada, malzeme taşıma sisteminin bir parçası ol- duğu entegre bir üretim sistemi düşünülmemiştir. $\mathrm{Bu}$ nedenle fabrika yerleşimi, makineler ve malzeme akış rotaları bu çalışmanın kapsamına konulmamıştır. Sadece fabrika yerleşimi ve malzeme akış rotaları ile ilgili olarak hazırlanmış programlar da UZMANIM programı ile birlikte kullanılarak bu eksikliğin giderilebileceği düşünülmüştür. (Yurdakul ve İpek, 2005, s.171-181)

Mahmoodzadeh, Shahrabi, Pariazar ve Zaeri, , net bugünkü değer, fayda maliyet analizi, getiri oranı ve geri ödeme suresi gibi kriterleri proje değerlendirme yöntemlerine dayanarak bulanık AHP ve TOPSIS yöntemlerini kullanarak farklı projelerin tercih sıralamasını belirlemişlerdir. (Mahmoodzadeh vd., 2007, s.135-140)

Önüt ve Soner, atık aktarma yer sorunu için de AHP yöntemi ile ağırlıkları belirledikten sonra bulanık TOPSIS yöntemi ile problemi çözmüşlerdir. Endüstriyel katı atığa yakınlık, evsel katı atığa yakınlık, ulaşım kolaylığı, gereklilik, yerleşim alanına yakınlık gibi kriterler baz alınmıştır. (Önüt ve Soner, 2008, s.1552-1558).

Kannan v.d. ters lojistik sağlayıcıların seçimi için bilgisayar destekli bir öğrenme süreci olan ISM (Interpretive Structural Modeling) ve bulanık TOPSIS yöntemlerini birlikte kullanmışlardır. kalite, teslim, ters lojistik maliyeti, iade oranı, teknik mühendislik yeteneği, gelecekteki ihtiyaçlarını karşılama kabiliyeti, istek ve tutum gibi kriterler dikkate alınmıştır. (Kannan vd., 2009, s.28-36)

Dağdeviren vd., silah seçimi için AHP ve bulanık TOPSIS yöntemlerini birlikte kullanmışlardır. AHP yöntemi ile öncelikle ağırlıklar belirlenmiş daha sonra bulanık TOPSIS yöntemi uygulanmıştır. Üretim süreci, geri tepme sistemi, hassasiyet, ağırlık, farklı iklim koşullarında kullanılabilirlik ve bakım, modülerlik, tetik sistemi, güvenlik mekanizması, görüş sistemi, fiyat gibi kriterler dikkate alınmıştır (Dağdeviren vd., 2009, s.8143-8151).

Amiri, bir petrol şirketi için en iyi projeyi seçmek için AHP ve bulanık TOPSIS yöntemlerini uygulamışlardır. Proje seçimi için boyut/karmaşıklık, tahmini maliyet, kapsam-yeterlilik-ayrıntı düzeyi, süre, teknoloji ve konum gibi kriterler dikkate alınmıştır. Bu çalışmada da yine AHP yöntemi ile ağılıklar belirlenmiş daha sonra bulanık TOPSIS yöntemi uygulanmıștır. (Amiri, 2010, s.6218-6224). 
Supçiller ve Çapraz, tedarikçi seçimi problemini ele almışlardır. Çok kriterli karar verme yöntemlerinden AHP ve TOPSIS yöntemleri birlikte uygulanmıștır. Çalışmada, kalite, maliyet, teslimat ve hizmet kriterleri ana kriterler olarak belirlenmiştir ve bu ana kriterlerin alt kriterleri de tanımlanmıştır. AHP yöntemi ile ana kriterler ve alt kriterlerin önem dereceleri belirlenmiş, TOPSIS yöntemi ile de bu kriterler doğrultusunda tedarikçilerin sıralaması yapılmıştır. Çalışma sonunda en önemli kriter "kalite" olarak belirlenmiş ve işletmenin mevcut tedarikçileri arasında "A2 tedarikçisi” en yüksek puana sahip tedarikçi olarak seçilmiştir. (Supçiller ve Çapraz, 2011, s.1-22)

Abalı, Kutlu ve Eren, çalışmalarında burs veya yardım alacak öğrencilerin belirlenmesinde göz önünde bulundurulacak ölçütlerin önceliği AHP ve TOPSIS yöntemleri ile belirlenmiştir. Çalışmada; ailenin bakmakla yükümlü olduğu çocuk sayısı, ailenin toplam aylık geliri, anne-baba durumu, ailenin sahip olduğu mülk sayısı ve öğrencinin çalışma durumu kriterleri doğrultusunda 5 alternatif değerlendirilmiştir. (Abalı vd., 2012, s.259-272)

Wang v.d. tedarikçi seçiminde bulanık hiyerarşik TOPSIS yöntemini uygulamışlardır. Maliyet, kalite ve hizmet olmak üzere üç ana kriter ve yedi alt kriter belirlemişlerdir.(Wang vd., 2009, s.377-386)

Awasthi ve Chauhan, sürdürülebilir șehir lojistik planlama için AHP ve bulanık TOPSIS yöntemlerini birlikte kullanmışlardır. Teknik, sosyal, ekonomik ve çevresel olmak üzere 4 ana kriter altında yer alan toplam 16 alt kriter dikkate alınmıştır. Öncelikle AHP yöntemi ile ağırlıklar belirlenmiş daha sonra bulanık TOPSIS yöntemi uygulanmıştır. (Awasthi ve Chauhan, 2012, s.573-584).

Ignatius vd., bir üniversitenin kaynak tahsisi için AHP ve bulanık TOPSIS yöntemlerini uygulamışlardır. Sürdürülebilirlik ve fayda ana kriterleri altında on üç adet alt kriter belirlenmiştir. Öncelikle AHP yöntemi ile ağırlıklar belirlenmiş daha sonra bulanık TOPSIS yöntemi uygulanmıştır ( Ignatius vd, 2012, s.3329-3340).

\section{Çok Kriterli Karar Verme}

Çok kriterli karar verme problemi için SAW, AHP, ANP, TOPSIS, VIKOR, ELECTRE gibi birçok metot ortaya konulmuştur. Ancak bilginin belirsiz ve kesin olmadığı durumlarda öznel bir karar için net bir değer atamak gerçekçi olmamaktadır. Bu sebeple öznel karar verme sürecini modelleyebilmek, insan yargisındaki belirsizliği ve öznelliği gidermek ve karar verme aşamasında dilsel ifadeleri açılamak için bulanık küme teorisi 1965 yllında Zadeh tarafından ortaya atılmıştır. (Wang ve Chang, 2007, s.871, Chang ve Wang, 2009, s.356)

Birçok gerçek uygulamada belirsizliklerle uğraşmak gerçekten zor olabilmektedir. Matematiksel modeller karar vericinin belirsizlikleriyle uğraşmazlar. Nümerik değerlerden çok dilsel değerleri kullanmak daha iyidir. $\mathrm{Bu}$, problemin kriter ağırlıklarının ve puanların dilsel değişkenlerle değerlendirilmesi anlamına gelmektedir. Bulanık küme teorisi, karar modelinde elde edilemeyen, tamamlanamayan ve sayllamayan bilgiyi dahil etmek için karar vericiye dilsel değişkenleri kullanmasına müsaade etmektedir. (Kulak vd., 2005, s.337-338).

Klasik küme kavramı, bir nesnenin bir kümenin elamanı olması ya da olmaması gibi iki seçeneğe dayanmaktadır. Eğer nesne o kümenin elemanı ise "1", elemanı değilse "0" değerini alır. Bulanık küme ise değişik üyelik derecesinde öğeleri olan bir topluluktur. Burada " 0 " değeri üye olmamayı, "1" değeri tam üye olmayı belirtirken $(0,1)$ arası değerler de kısmi üyelik kavramına karşlık gelmektedir. Çok sayıda üyelik fonksiyonu tipi bulunmakla beraber en çok üçgen, yamuk, çan eğrisi, Gaussian ve sigmoidal fonksiyonları kullanılmaktadır. (Baykal ve Beyan, 2004, s.74-75).

Bulanık çok kriterli karar verme analizi belirsiz koşullarda bir ya da birden fazla alternatifin ve özelliğin olduğu problemlerde yaygın olarak kullanılmaktadır. (Chang ve Wang, 2009, s.356) Bulanık çok kriterli karar verme metodolojisini başlatan araştırmacılar 1970 yılındaki çalışmaları ile Zadeh ve Bellman olmuştur. Daha sonra birçok araştırmacı tarafından farklı çalışmalar yapılmıştır. (Wang ve Chang, 2007, s.871, Chang ve Wang, 2009, s.356)

Bu çalışmada ise AHP temelli Bulanık TOPSIS yöntemi ile en iyi tur operatörünün seçimi üzerine bir uygulama yapılmıştır.

\section{Analitik Hiyerarşi Prosesi}

İlk olarak 1968 yllında Myers \& Alpert tarafindan ortaya atılan (Eroğlu ve Lorcu, 2007, s.32.), Thomas Saaty tarafından 1970 'li yıllarda geliştirilen Analitik Hiyerarşi Prosesi (AHP - Analytic Hierarchy Process), karar vericilerin karmaşık problemleri, problemin 
ana hedefi, kriterleri, alt kriterler ve alternatifleri arasındaki ilişkiyi gösteren bir hiyerarşik yapıda modellemelerini sağlamaktadır. Karar vericinin hem objektif hem de subjektif düşüncelerini karar sürecine dahil edebilmesi Analitik Hiyerarşi Prosesinin en önemli özelliğidir. AHP, bilginin, deneyimin, bireyin düşüncelerinin ve önsezilerinin mantıksal bir şekilde birleştirildiği birçok karar probleminde etkin olarak kullanılan bir yöntemdir.(Kuruüzüm ve Atsan, 2001, s.84) $\mathrm{Bu}$ yöntem sayesinde, karar verme aşamasında karar vericiler uzmanlık alanlarına göre, mesleki bilgi ve deneyimleri etkin olarak kullanabilmektedir.(Maden, 2007, s.14.)

AHP, gruplara ve bireylere karar verme aşamasındaki nitel ve nicel faktörleri birleştirme olanağı sağlayan güçlü ve kolay anlaşılır bir yöntemdir.(Saaty, 1990, s.20.) AHP'de her problem için amaç, kriterler/alt kriterler ve önem düzeyleri matrislerinden oluşan ve hiyerarşilerin oluşturulması, üstünlüklerin belirlenmesi, mantıksal ve sayısal tutarlılığın sağlanması gibi üç temel prensip üzerine kurulan hiyerarşik bir model kullanılmaktadır. (Eleren, 2007, s.51.)

Hiyerarşi kullanımı karışık sistemleri yorumlayabilmek için etkin bir yoldur. Hiyerarşideki tüm parçalar birbirleri ile ilgilidir ve bir kriterdeki değişimin diğer kriterleri nasıl etkilediği kolayca görülebilmektedir. Karar vericinin karar sürecinde AHP’nin hiyerarşik yapısındaki bu esneklik ve etkinlik yardımcı olmaktadır.(Güner vd., 2007, s.74.) AHP’de problem Şekil 1.de görüldüğü gibi hiyerarşik bir biçimde yapılandirılmaktadır.

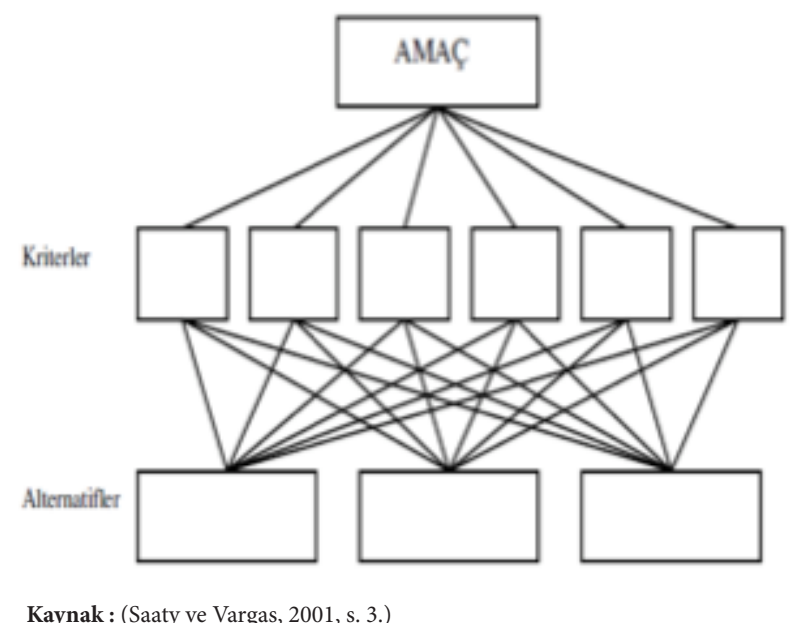

Şekil 1. ÜçSeviyeli Analitik Hiyerarşi Modeli

AHP ile öncelikleri oluşturarak karar vermek için aşağıdaki adımlar izlenmelidir;(Saaty, 2008, s.85.)

- Problem tanımlanmalı ve aranan bilginin türü belirlenmeli,

- En tepede karara ait hedef, orta seviyede kriterler ve en alt seviyede ise alternatifler olacak şekilde hiyerarşik yapı oluşturulmalı,

- İkili karşılaştırma matrisleri oluşturulmalı ve her seviye için ayrı ayrı uygulanmalı,
- Her eleman için ayrı ayrı öncelikler elde edilmeli ve bu işleme en alt seviyedeki ağırlıklar elde edilinceye kadar devam edilmelidir.

İkili karşılaştırmalarda 1-9 arasındaki bir skala kullanılır ve karar vericide bu skalayı temel alarak kriterler arasındaki önem derecesine karar vermektedir. Yapılan karşılaştırma sonucu tutarlı olup olmadığı değerlendirilmektedir. 1-9 skalası Tablo1'de gösterilmiştir. 
Tablo 1. Analitik Hiyerarşi Sürecinde Kullanılan Ölçek

\begin{tabular}{|c|l|}
\hline DERECELER & TANIM \\
\hline 1 & Öğeler eşit önemde veya aralarında kayıtsız kalınıyor \\
\hline 3 & 1. öğe 2.'ye göre biraz daha önemli veya biraz daha tercih ediliyor \\
\hline 5 & 1. öğe 2.'ye göre fazla önemli veya fazla tercih ediliyor \\
\hline 7 & 1. öğe 2.'ye göre çok fazla önemli veya çok fazla tercih ediliyor \\
\hline 9 & 1. öğe 2.'ye göre aşırı derecede önemli veya aşırı derecede tercih ediliyor \\
\hline $2-4-6-8$ & Ara Değerler \\
\hline
\end{tabular}

Kaynak: (Saaty, 2008, s. 85.)

AHP’nin temelini oluşturan 4 temel aksiyomu Saaty şöyle tanımlamıştır(Saat, 2000, s.152.):

\begin{abstract}
Aksiyom 1 (Terslik Koşulu): Karar verici, karşılaştırmalar yapabilmeli ve tercihlerinin derecesini belirleyebilmelidir. $\mathrm{Bu}$ tercihlerin derecesi terslik koşulunu sağlamaktadır. Eğer A, B’ nin x katı olarak tercih ediliyorsa, B' nin A' ya göre tercih derecesi 1 /x olmaktadir.
\end{abstract}

Aksiyom 2( Homojenlik): Homojenlik benzer öğelerin karşılaştırılması için gereklidir. Örneğin bir kum tanesi ile portakalı büyüklük açısından karşılaştırmaya tabi tutulamaz. Karşılaştırılan ögeler homojen olmadığı zaman öğelerin kümelenmesi gerekmektedir.

Aksiyom 3(Bağımsızlık): Tercihler ifade edildiği zaman, kriterlerin alternatiflerden bağımsız olduğu varsayılmaktadır. Aksiyom 4 (Beklentiler): Hiyerarşik modelin karar verme amaciyla tamamlandığ ylmaktadır.

AHP’nin aşamaları incelendiğinde; ilk aşamasında karar probleminin hiyerarşik yapısı yani karmaşık yapıdaki problemde en üstten en alta doğru gidilerek, amaç, kriterler, alt kriterler, alternatifler belirlenmektedir. Bu hiyerarşi en üstte amacın yer aldığı genel durumdan, en altta alternatiflerin yer aldığı özel olan duruma ulaşmayı sağlamaktadır.(Doğan, 2004, s.10.) Problem hiyerarşik bir yapı içinde ele alındığında, probleme ait bileşenleri karşılaştırma, ilgili bileşenlere ait yargida bulunma ve alternatifleri karar faktörleri açısından değerlendirme imkânı doğmaktadır.(Timor, 2004:8.) Ortaya çıabilecek herhangi bir karmaşa hiyerarşi oluşturularak engellenmekte aynı zamanda problemin temel unsurlarının belirlenmesi de sağlanmaktadır.(Wind ve Saaty, 1980, s.642.)

AHP'nin ikinci aşamasında, hiyerarşide yer alan iki öğe arasındaki ilişkilerin sayısal olarak temsil edilmesini sağlayan karşılaştırma yapılmaktadır. Yapılan karşılaştırma, kare matris şeklinde olan ikili karşılaştırmalar matrisi olarak ifade edilmektedir. Her bir değerlendirme iki kriter arasında hangisinin daha önemli olduğunu ortaya koymakta ve bu önemin derecesini yansıtmaktadır. Tüm öğelerin ikili karşılaştırmaları sonucunda ikili karşılaştırma matrisi oluşturulmaktadır. Oluşturulan ikili karşılaştırma matrisinde bir öğenin kendisiyle karşılaştırılması 1 ile ifade edildiğinden matrisin köşegenlerine 1 değerleri yerleştirilir. $n$ elemanlı bir matriste $\left[n^{\star}(n-1)\right] / 2$ adet karşılaştırma yapılır. (Güner, 2003, s.2.)

AHP'nin üçüncü aşamasında, oluşturulan matrislerin tutarlı olup olmadığını gösteren uyum oranı hesaplanmaktadır. Uyum oranı 0.1 den küçükse tutarllı̆̆g ifade etmektedir. 0,1'den büyük çıkarsa yeniden değerlendirme yapılması gerekmektedir. Uyum oranı hesaplanırken öncelikle karşılaştırma matrisinin her bir satırı için, sütunlarda yer alan elemanların ağırlikları toplamı bulunur ve her bir sütundaki eleman bu ağırlıklara bölünerek normalize edilmiş matris değerlerine ulaşılır. $\mathrm{Bu}$ normalize edilmiş matrisin her satırının ortalaması alınarak öncelikler vektörü hesaplanır. Daha sonra ise öncelikler vektörüyle karşlaştırma matrisi çarpılarak tüm öncelikler matrisi elde edilmektedir. CI (tutarlılık indeksi) aşağıdaki gibi hesaplanır:

$\mathrm{CI}=\left(\lambda_{\text {max }}-\mathrm{n}\right) /(\mathrm{n}-1)$

Tutarlılık oranı (CR) da aşağıdaki gibi hesaplanmaktadir

\section{$\mathrm{CR}=\mathrm{CI} / \mathrm{RI}$}

$\lambda_{\max }$ bir kare matrisin özdeğerleri arasındaki en büyük değeri göstermektedir. RI:Rasgele değer indeksini ifade etmekte olup Tablo 2 de verilen değerlerden uygun olanı seçilerek işlemlerde kullanılmaktadır.(Timor, 2011, s.44.) 
Tablo 2. Rastgele Indeks Tablosu

\begin{tabular}{|c|c|c|c|c|c|c|c|c|c|c|c|c|c|c|c|}
\hline $\mathrm{n}$ & 1 & 2 & 3 & 4 & 5 & 6 & 7 & 8 & 9 & 10 & 11 & 12 & 13 & 14 & 15 \\
\hline R.I. & 0.00 & 0.00 & 0.58 & 0.90 & 1.12 & 1.24 & 1.32 & 1.41 & 1.45 & 1.49 & 1.51 & 1.48 & 1.56 & 1.57 & 1.59 \\
\hline
\end{tabular}

Kaynak: (Saaty ve Tran, 2007, s.966.)

\section{TOPSIS Yöntemi}

TOPSIS yöntemi Hwang ve Yoon tarafından 1981 y1linda ortaya konulmuștur. Akabinde Chen ve Hwang (1992) tarafindan, Hwang ve Yoon (1981)'nun geliştirdiği yöntemi bulanık durumlara uygulamasıyla gerçekleşmiştir. Daha sonraki bulanık TOPSIS çalışmalarında ise, Liang (1999), bulanık çok nitelikli karar verme problemi için ideal ve ideal olmayan noktalara dayalı bir yöntem geliştirerek, bu yöntemle farklı kriterlerin ağırlıklarını ortaya koymak ve değerlendirebilmek için alternatiflerin her bir kriter ile karşılaştırıldığı karar matrislerinden faydalanarak bulanık küme teorisini ve hiyerarşik yapı kavramlarını bir arada kullanmıştır. (Erginel vd., 2010, s.82).

\section{Bulanık TOPSIS Yöntemi}

TOPSIS yöntemi Hwang ve Yoon tarafından 1981 yılında ortaya konulmuştur. TOPSIS yöntemi çok kriterli karar verme problemlerini çözmek için kullanıcı tarafından seçilen seçeneğin pozitif ideal çözüme en yakın ve negatif ideal çözümden en uzak olmasını sağlayan bir yöntem olarak bilinmektedir. Pozitif ideal çözüm faydaları maksimum düzeye çıarırken maliyetleri minimum yapmaya çalışmakta, negatif ideal çözüm ise maliyetleri en üst düzeye çıkarırken faydaları minimize etmeye çalışmaktadır (Huang ve Peng, 2012, s.458, Wang vd., 2007, s.2). Yani en iyiden (pozitif ideal) en kötü (negatif ideal) noktaların mesafelerini ortaya koyarak alternatifleri siralayan bir yöntemdir (Ignatius vd., 2012, s.3332).

Birçok durumda insan tercihleri tam olarak net değildir ve belirsizlik içerebilmektedir. Kişiler kriterleri değerlendirirken net değerler vermek istemeyebilirler. Ayrıca bazı kriterleri değerlendirirken net değerlerle ifade etmek zor olabilmektedir. Bu durumda klasik TOPSIS yöntemi yerine, bulanık TOPSIS yöntemi tercih edilmektedir. Çok sayıda üyelik fonksiyonu bulunmakla beraber bu çalıșma da hesaplamanın daha kolay olması nedeniyle üçgen bulanık sayılar tercih edilmiștir (Amiri, 2010, s.6219)

Tanım 1: Bir bulanık üçgensel sayı olan $a=\left(a_{1}, a_{2}, a_{3}\right)$ şeklinde ifade edilmektedir. Bir bulanık üçgensel sa- yının şekil olarak gösterimi Şekil 2.de verilmektedir. (Awasthi ve Chauhan, 2012, s.576).

$$
\mu_{\tilde{a}}(x)=\left\{\begin{array}{cc}
0, & x<a_{1} \\
\frac{x-a_{1}}{a_{2}-a_{1}}, & a_{1} \leq x \leq a_{2} \\
\frac{x-a_{3}}{a_{2}-a_{3},} & a_{2} \leq x \leq a_{3} \\
0, & x>a_{3}
\end{array}\right.
$$

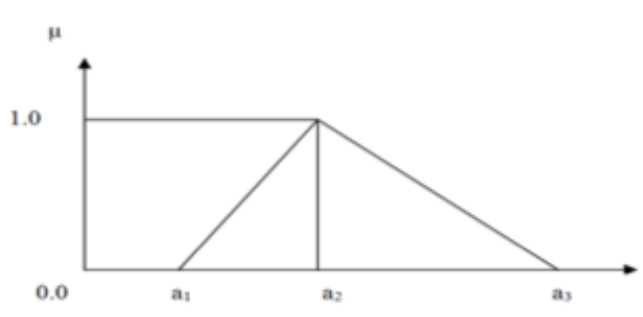

Şekil 2. Bulanık Üsgensel Sayı

Burada yer alan $a_{1}, a_{2}, a_{3}$ sayıları gerçek sayılardır ve $a_{1} a_{2} a_{3}$ dür. $a_{2}$ 'de x'in değerinin maksimum derecesi $\mu_{\tilde{a}}(x)$ verilir ve $\mu_{\tilde{a}}(x)=1$ 'dir. Bu değer, değerlendirilen verinin alabileceği en büyük değeridir. $a_{1}$ 'de $\mathrm{x}$ değerinin minumum derecesi $\mu_{\tilde{a}}(x)$ verilir ve $\mu_{\tilde{a}}(x)=0$ 'dır. Bu değer ise değerlendirilen verinin alabileceği en az değerdir. $\left[a_{1}, a_{3}\right]$ aralığı değerlendirilen verinin en bulanık olduğu aralıktır.

Tanım 2: Bulanık küme teorisi dilsel değişkenleri dönüştürmek için bulanık sayıları kullanmaktadır. Alternatif ve kriterlere puan verirken 1-9 arasındaki ölçek kullanılmaktadır (Tablo 1). Alternatifler için kullanılan dilsel değişkenler ve bulanık aralıklar Tablo 3.te verilmiştir. Kriterler ile alternatifler arasındaki ilişki dereceleri dilsel değişkenler kullanılarak belirlenmekte ve bulanık sayılar ile ifade edilmektedir. 
Tablo 3. Seçim Kriterlerinin Dilsel Ifadelerinin Bulanık Üçgen Sayılar ile Derecelendirilmesi

\begin{tabular}{|c|c|}
\hline Dilsel Değişkenler & Bulanık üçgen sayılar \\
\hline Hiç önemli değil & $(0.0,0.0,0.2)$ \\
\hline Önemli değil & $(0.0,0.2,0.4)$ \\
\hline Orta derecede önemli & $(0.3,0.5,0.7)$ \\
\hline Oldukça önemli & $(0.6,0.8,1.0)$ \\
\hline Çok önemli & $(0.8,1.0,1.0)$ \\
\hline
\end{tabular}

Bulanık TOPSIS'in adımları ise aşağıdaki gibidir: Chen, 2000, s.3-6, Wang ve Chang, 2007, s.871-872, Awasthi ve Chauhan, 2012, s.577-579)

Adım 1: Alternatiflere ve kriterlere puanlarin atanmast: ( $m$ tane alternatif var ise $A=\left\{A_{1}, A_{2}, \ldots . .\right.$. , $\left.A_{m}\right\}$ ve $n$ tane de kriter var ise $C=\left\{C_{1}, C_{2}, \ldots . ., C_{n}\right\}$. Kriter ağırlıkları $w_{j}(j=1,2, \ldots \ldots, n)$ 'dir. $B u$ çalışmada kriterlerin ağırlıkları AHP yöntemi ile belirlenmiştir. Kriterlere göre $C_{j}(j=1,2, \ldots \ldots, n)$, her bir alternatif için $A_{i}\left(A_{1}, A_{2}, \ldots \ldots ., A_{m}\right)$ her karar vericinin $\mathrm{D}_{\mathrm{k}}(\mathrm{k}=1,2, \ldots \ldots, \mathrm{k}) \mu_{\tilde{R}_{k}}(x)$ üyelik fonksiyonu ile performans puanlar1 $R_{k}=X_{i j k}(\mathrm{i}=1,2, \ldots \ldots$. , $m ; j=1,2, \ldots \ldots, n ; k=1,2, \ldots \ldots, K)$ şeklinde gösterilir.

Adım 2: Alternatifler ve kriterler için toplam bulanık puanlarin hesaplanması :

Bütün karar vericilerin bulanık puanları üçgen bulanık sayı olarak tanımlanırsa $\tilde{R}_{k}=\left(\mathrm{a}_{\mathrm{k}}, \mathrm{b}_{\mathrm{k}}, \mathrm{c}_{\mathrm{k}}\right), \mathrm{k}=1$, 2, ...., K. bulanık puanların toplamı $R=(\mathrm{a}, \mathrm{b}, \mathrm{c}), \mathrm{K}$ $=1,2, \ldots, \mathrm{K}$ olarak verilir. Burada;

$a=\min _{k}\left\{a_{k}\right\}, b=\frac{1}{K} \sum_{k=1}^{K} b_{k}, c=\max _{k}\left\{c_{k}\right\}$.

Eğer k. karar verici bulanık puanları $x_{i j k}=\left(a_{i j k}, b_{i j k}\right.$, $\left.c_{i j k}\right) i=1,2, \ldots, m, j=1,2, \ldots, n$ şeklinde tanımlarsa her kritere göre alternatiflerin $\left(x_{i j}\right)$ bulanık puanlarının toplamı $\tilde{x}_{i j}=\left(\mathrm{a}_{\mathrm{ij}}, \mathrm{b}_{\mathrm{ij}}, \mathrm{c}_{\mathrm{ij}}\right)$ şeklinde verilir. Burada;

$\mathrm{a}_{\mathrm{ij}}=\min _{k}\left\{a_{i j k}\right\}, \mathrm{b}_{\mathrm{ij}}=\frac{1}{K} \sum_{k}^{K} b_{i j k}, \mathrm{c}_{\mathrm{ij}}=\max _{k}\left\{c_{i j k}\right\}$.

$\mathrm{j}=1,2, \ldots, \mathrm{n}$ kriterin ağırlıkları $\mathrm{w}_{\mathrm{j}}, \mathrm{k}$ adet karar vericiden elde edilen ağırlıkların ortalamasıdır. $\mathrm{Bu}(4)$ formüldeki gibi hesaplanır:

$w_{j}=\frac{w_{j 1}+w_{j 2}+w_{j 3}}{k}$.

Adım 3: Bulanik karar matrisinin hesaplanmasi:

Alternatifler için bulanık karar matrisi $\widetilde{D}$ ile gösterilirse:

$\tilde{D}=A_{1}\left[\begin{array}{ccc}x_{11} & \cdots & x_{1 n} \\ \vdots & \ddots & \vdots \\ A_{m} & \cdots & \\ x_{m 1} & \cdots & x_{m n}\end{array}\right] \mathrm{i}=1,2, \ldots, \mathrm{m} ; \mathrm{j}=1,2, \ldots, \mathrm{n}$.
Adım 4: Bulanık karar matrisinin normalize edilmesi:

Ham verilerin karşılaştırılabilir bir ölçeğe çeşitli kriterlerin ölçümünü yapabilmek için doğrusal bir ölçek dönüşümü kullanarak normalize edilmelidir. Normalize edilen bulanık karar matrisi $\widetilde{R}$ ile gösterilirse:

$\tilde{R}=\left[\tilde{r}_{i j}\right]_{m * n}, \mathrm{i}=1,2, \ldots, \mathrm{m} ; \mathrm{j}=1,2, \ldots, \mathrm{n}$,

Burada,

$r_{i j}=\left(\frac{a_{i j}}{c_{j}^{*}}, \frac{b_{i j}}{c_{j}^{*}}, \frac{c_{i j}}{c_{j}^{*}}\right)$ ve $c_{j}^{*}=\max _{i} c_{i j}$ (fayda kriteri).

$r_{i j}=\left[\frac{a_{j}^{-}}{c_{i j}}, \frac{a_{j}^{-}}{c_{i j}}, \frac{a_{j}^{-}}{c_{i j}}\right]$ ve $a_{j}^{-}=\min _{i} a_{i j}$ (maliyet kriteri).

Adım 5: Ağırlıklandırılmış normalize edilmiş matrisin hesaplanmasi:

Kriter için ağırlıklandırılmış normalize edilmiş matris $\nabla$ normalize edilmiş bulanık karar matrisi ile değerlendirme kriterinin ağırlığı $\mathfrak{r}_{i j}$ 'nin çarpılması ile bulunur.

$\nabla=\left[v_{i j}\right]_{m * n}, \mathrm{i}=1,2, \ldots, \mathrm{m} ; \mathrm{j}=1,2, \ldots, \mathrm{n}$ burada $v_{i j}=r_{i j}(*) w_{j}$.

Burada $\mathfrak{v}_{i j},\left(a_{i j}, \tilde{b}_{i j}, c_{i j}\right)$ ile gösterilen bulanık üçgen sayıdır.

Adım 6: Bulanık pozitifideal çözüm (BPİÇ) ve bulanık negatif ideal çözüm (BNIÇ) hesaplanması:

Alternatiflerin (BPIÇ) ve (BNIÇ) değerleri aşağıdaki gibi hesaplanır:

$$
\begin{aligned}
& A^{*}=\left(v_{1}^{*}, v_{2}^{*}, \ldots, v_{n}^{*}\right) v_{j}^{*}=\left(c_{j}^{*}, c_{j}^{*}, c_{j}^{*}\right) \text { ve } c_{j}^{*}=\max _{i}\left\{c_{i j}\right\}, \\
& A^{-}=\left(v_{1}^{-}, v_{2}^{-}, \ldots, v_{n}^{-}\right) v_{j}^{-}=\left(a_{j}^{-}, a_{j}^{-}, a_{j}^{-}\right) \text {ve } c_{j}^{-}=\min _{i}\left\{a_{i j}\right\}, \\
& \forall i=1,2, \ldots, m ; \quad j=1,2, \ldots ., n .
\end{aligned}
$$

Adım 7: (BPİÇ) ve (BNİÇ) değerlerinden her bir alternatifin uzakliklarinin hesaplanmasl:

$$
\begin{aligned}
& d_{i}^{+}=\sum_{j=1}^{n} d_{v}\left(\tilde{v}_{i j}, v_{j}^{*}\right), i=1,2, \ldots, m, \\
& d_{i}^{-}=\sum_{j=1}^{n} d_{v}\left(v_{i j}, v_{j}^{-}\right), i=1,2, \ldots, m,
\end{aligned}
$$

Burada $\quad d_{v}(\tilde{a}, \bar{b})$ a ve $\tilde{b}$ olarak verilen iki bulanık sayı arasındaki uzaklıktır ve bu uzaklığın ölçümü aşağıdaki eşitlikte verilmiştir. 
$d_{v}(\widetilde{a}, \bar{b})=\sqrt{\frac{1}{3}\left[\left(a_{1}-b_{1}\right)^{2}+\left(a_{2}-b_{2}\right)^{2}+\left(a_{3}-b_{3}\right)^{2}\right]}$

Adım 8: Her bir alternatif için yakınlık katsayısı $C C_{i}$ 'nin hesaplanmasl:

Yakınlık katsayısı $C C_{i}$ aşağıdaki eşitlik yardımı ile hesaplanır:

$C C_{i}=\frac{d_{i}^{-}}{d_{i}^{-}+d_{i}^{+}}, i=1,2, \ldots, m$.

Adım 9: Alternatiflerin siralanması:

$\mathrm{Bu}$ adımda her bir alternatif yakınlık katsayısı $C C_{i}$ değerlerine göre sıralanır. $C C_{i}$ değeri en yüksek olan alternatif en iyi alternatiftir. Bu alternatif bulanik negatif ideal çözüme en uzak, bulanık pozitif ideal çözüme en yakın alternatiftir.

Yakınlık katsayısı $\mathrm{CC}_{\mathrm{i}}$ değerinin l'e yakın olması BPİÇ’e yaklaştığının göstergesidir. Yakınlık katsayısının l'e yakın olması alternatifin tercih edilme şansını artıracaktır. Her bir alternatifin yakınlık katsayısını dilsel değişken kullanarak $[0,1]$ aralığında beş sınıfa ayırarak değerlendirilebilir. Değerlendirme sonuçları aşağıdaki tabloda verilmiştir (Chen vd., 2006:296).

Tablo 4. Yakınlık Katsayısının (CC) Kabul Koşulları

\begin{tabular}{|c|c|}
\hline Yakınlık Katsayısı $\left(\mathbf{C C}_{\mathrm{i}}\right)$ & Değerlendirme \\
\hline $\mathrm{CC}_{\mathrm{i}} \in[0,0.2)$ & Tavsiye edilmez. \\
\hline $\mathrm{CC}_{\mathrm{i}} \in[0.2,0.4)$ & Yüksek risk ile tavsiye edilir. \\
\hline $\mathrm{CC}_{\mathrm{i}} \in[0.4,0.6)$ & Düşük risk ile tavsiye edilir. \\
\hline $\mathrm{CC}_{\mathrm{i}} \in[0.6,0.8)$ & Kabul edilir. \\
\hline $\mathrm{CC}_{\mathrm{i}} \in[0.8,1.0]$ & Kabul edilir ve tercih edilir. \\
\hline
\end{tabular}

\section{Tur Operatörü Seçiminde AHP ve Bulanık TOPSIS Yöntemlerinin Uygulanması}

$\mathrm{Bu}$ çalışmada Isparta ilinde yeni kurulan 5 yıldızlı bir otel için en uygun ve en iyi getiriyi sağlayacak tur operatörünün belirlenmesine çalışılmıştır. $\mathrm{Bu}$ amaçla uygun tur operatörü belirlenmesinde etkili olan iki ana kriter (Tur Operatörüne Yönelik Kriterler ve Otele Yönelik Kriterler) ve alt kriterler ilgili uzman kişilerle görüşülerek Tablo 5’teki gibi belirlenmiştir.

Tablo 5. En Uygun Tur Operatörü Seçiminde Etkili Olan Kriterler ve Kodları

\begin{tabular}{|c|l|l|}
\hline \multirow{5}{*}{ Tur Operatörüne Yönelik Kriterler } & TK & Türsab'a Kayıtlı Olması \\
\cline { 2 - 3 } & YM & Yasal Mevzuata Uygunluk \\
\cline { 2 - 3 } & T & Tanınmışlık \\
\cline { 2 - 3 } & RP & Reklam, Promosyon Saha Genişliği \\
\cline { 2 - 3 } & GB & Geçmiş Dönem Borçlarının Olmaması \\
\cline { 2 - 3 } & ÖS & Ödemede Sağlamlık \\
\cline { 2 - 3 } & ZS & Zorunlu Sigorta Hizmeti \\
\cline { 2 - 3 } & GÜ & Güvenirlilik \\
\cline { 2 - 3 } Otele Yönelik Kriterler & SE & Sermayesi \\
\hline & AS & Anlaşmanın Sürekliliği \\
\cline { 2 - 3 } & ON & Oncelik \\
\cline { 2 - 3 } & GMS & Getireceği Müşteri Sayısı \\
\cline { 2 - 3 } & KGS & Konaklama Gün Sayısı \\
\hline
\end{tabular}

Çalışmada belirlenen kriterler doğrultusunda değerlendirilecek alternatif tur operatörlerinin belirlenmesinde günümüzde kullanımı çok yaygın olan Facebook ve Twitter sosyal ağlarından faydalanılmıştır. Tur operatörleri belirlenirken 14.03.2013 tarihli Facebook'taki beğeni ve Twitter'deki takipçi sayıları dikkate alınmıştır. Tablo 6 incelendiğinde en fazla beğeni / takipçi sayısının olduğu ve otelin bu konularla deneyimli ve ilgili personelinin de görüşleri doğrultusunda Anitur, Tatil.com, ETS Tur ve JOLLY Tur alternatif tur operatörleri olarak belirlenmiştir. 
Tablo 6. Alternatif Tur Operatörlerinin Beğeni ve Takipçi Sayıları

\begin{tabular}{|l|c|c|}
\hline Tur Operatörleri & $\begin{array}{c}\text { Facebook Beğeni } \\
\text { Say1s } 1\end{array}$ & Twitter Takipçi Say1s1 \\
\hline ANITUR & 302.149 & 5.041 \\
\hline TATÍL.COM & 195.316 & 5.690 \\
\hline ETS TUR & 195.268 & 2.963 \\
\hline JOLLY TUR & 93.398 & 2.690 \\
\hline SE TUR & 47.414 & 1.060 \\
\hline CAFE TUR & 36.032 & 305 \\
\hline TOURISTICA & 22.379 & 1.378 \\
\hline BAMTUR & 11.138 & 723 \\
\hline MNG TUR & 91.107 & - \\
\hline PRONTO TUR & 3.341 & 299 \\
\hline
\end{tabular}

Kaynak : www.facebook.com, www.twitter.com, erişim tarihi: 14.03.2013

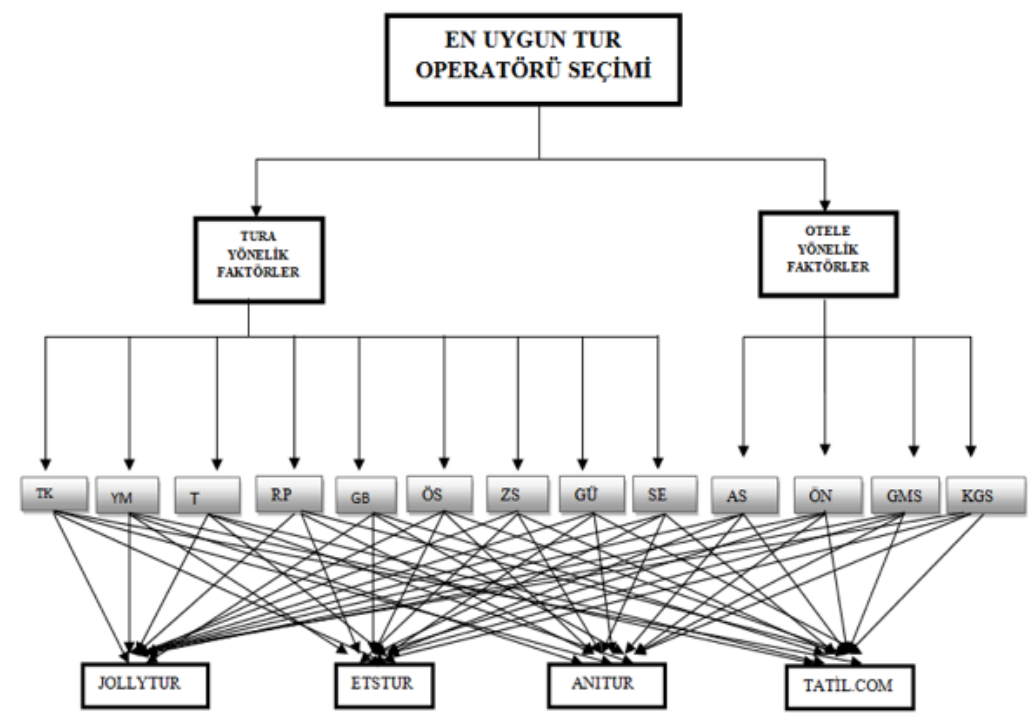

Şekil 3. Tur Operatörü Seçiminde Oluşturulan Hiyerarşik Yapı

Uygulamada tur operatörü seçiminde belirlenen kriterlerin ağırlıklarını elde edebilmek için AHP yönteminden yararlanılmıştır. AHP yönteminde oluşturulan hiyerarşik yapı Şekil 3.de gösterilmektedir.

Oluşturulan hiyerarşik yapı sonucunda AHP yönteminin uygulanabilmesi için oluşturulan ikili karşılaştırmalar otelin bu konularla deneyimli ve ilgili personeline yaptırılarak Expert Choice paket programında değerlendirilmiș olup, kriterlerin ağırlıkları Tablo 7.de görüldüğü gibi elde edilmiştir.
Tablo 7'de görüldüğü gibi; tur operatörüne yönelik ana kriter (0.875), otele yönelik ana kritere (0.125) göre daha önemlidir. Tur operatörüne yönelik alt kriterler incelendiğinde tur sermayesi (0.344), otele yönelik kriterler de ise konaklama gün sayısının (0.087) alt kriterlerinin en yüksek öneme sahip olduğu görülmektedir. AHP yöntemi ile elde edilen kriter ağırlıkları bulanık TOPSIS yönteminde kullanılarak otel için en uygun tur operatörü seçilmiştir. 
Tablo 7. Kriterlerin Genel Ağırlıkları

\begin{tabular}{|c|c|c|c|}
\hline Ana Kriterler & Kodlar & Alt Kriterler & Ăğ1rlıklar (W) \\
\hline \multirow{9}{*}{$\begin{array}{c}\text { TUR OPERATÖRÜNE } \\
\text { YÖNELİK KRİTERLER } \\
(0.875)\end{array}$} & TK & Türsab’a Kayıtlı Olması & 0.013 \\
\hline & YM & Yasal Mevzuata Uygunluk & 0.019 \\
\hline & $\mathrm{T}$ & Tanınmışlık & 0.028 \\
\hline & $\mathrm{RP}$ & Reklam, Promosyon Saha Genişliği & 0.035 \\
\hline & GB & Geçmiş Dönem Borçlarının Olmaması & 0.053 \\
\hline & ÖS & Ödemede Sağlamlık & 0.094 \\
\hline & ZS & Zorunlu Sigorta Hizmeti & 0.101 \\
\hline & GU & Güvenirlilik & 0.188 \\
\hline & $\mathrm{SE}$ & Sermayesi & 0.344 \\
\hline \multirow{4}{*}{$\begin{array}{l}\text { OTELE YÖNELİK } \\
\text { KRİTERLER } \\
(0.125)\end{array}$} & $\mathrm{AS}$ & Anlaşmanın Sürekliliği & 0.005 \\
\hline & ÖN & Öncelik & 0.010 \\
\hline & GMS & Getireceği Müşteri Sayısı & 0.023 \\
\hline & KGS & Konaklama Gün Sayısı & 0.087 \\
\hline
\end{tabular}

\section{Bulanık Topsis Uygulaması}

Adım 1: Kriter ağırlıklarının hesaplanması: AHP yöntemi kullanılarak kriter ağırlıkları hesaplanmıștır. Sonuçlar Tablo 7'de verilmektedir.

Adım 2: Karar vericinin karar kriterlerine göre alternatifleri dilsel değişkenlerle değerlendirmesi: Karar verici Tablo 3'te ki dilsel değişkenleri kullanarak kriterlere göre alternatifleri değerlendirmiştir. Değerlendirme sonuçlarına göre bulanık karar matrisi Tablo 8.de verilmektedir.
Adım 3: Normalleștirilmiş bulanık karar matrisinin olușturulması: Normalleștirilmiş bulanık karar matrisi en büyüklemek ve en küçüklemek kriterlerine bağlı olarak oluşturulur. Eğer bulanık karar matrisinde ilgilenilen kriteri en büyüklemek isiyorsak o kriteri baz alarak alternatifin aldığı değerleri sütün içindeki en büyük değere bölünür (Eşitlik 7), eğer bulanık karar matrisinde ilgilenilen kriteri en küçüklemek istiyorsak o kriteri baz alarak sütun içindeki en küçük değer alternatiflerin aldığı değerlere bölünerek (Eşitlik 8) normalleştirilmiş bulanık karar matrisi oluşturulur. Oluşturulan bulanık karar matrisi Tablo 9'da görülmektedir.

Tablo 8. Bulanık Karar Matrisi

\begin{tabular}{c|c|c|c|c|c|c|c|}
\hline & TK & YM & T & RP & GB & ÖS & ZS \\
\hline ANITUR & $(0.6,0.8,1)$ & $(0.6,0.8,1)$ & $(0.3,0.5,0.7)$ & $(0.3,0.5,0.7)$ & $(0,0.2,0.4)$ & $(0.3,0.5,0.7)$ & $(0.3,0.5,0.7)$ \\
\hline JOLLYTUR & $(0.8,1,1)$ & $(0.8,1,1)$ & $(0.6,0.8,1)$ & $(0.6,0.8,1)$ & $(0.6,0.8,1)$ & $(0.8,1,1)$ & $(0.6,0.8,1)$ \\
\hline ETSTUR & $(0.8,1,1)$ & $(0.8,1,1)$ & $(0.8,1,1)$ & $(0.8,1,1)$ & $(0.6,0.8,1)$ & $(0.8,1,1)$ & $(0.6,0.8,1)$ \\
\hline TATİL.COM & $(0.6,0.8,1)$ & $(0.8,1,1)$ & $(0,0.2,0.4)$ & $(0.3,0.5,0.7)$ & $(0.3,0.5,0.7)$ & $(0.8,1,1)$ & $(0.3,0.5,0.7)$ \\
\hline & GÜ & SE & AS & ÖN & GMS & KGS & \\
\hline ANITUR & $(0.3,0.5,0.7)$ & $(0,0.2,0.4)$ & $(0.3,0.5,0.7)$ & $(0.3,0.5,0.7)$ & $(0.3,0.5,0.7)$ & $(0.3,0.5,0.7)$ & \\
\hline JOLLYTUR & $(0.8,1,1)$ & $(0.3,0.5,0.7)$ & $(0.3,0.5,0.7)$ & $(0.8,1,1)$ & $(0.3,0.5,0.7)$ & $(0.8,1,1)$ \\
\hline ETSTUR & $(0.8,1,1)$ & $(0.3,0.5,0.7)$ & $(0.8,1,1)$ & $(0.8,1,1)$ & $(0.8,1,1)$ & $(0.8,1,1)$ \\
\hline TATİL.COM & $(0.6,0.8,1)$ & $(0,0.2,0.4)$ & $(0.3,0.5,0.7)$ & $(0.3,0.5,0.7)$ & $(0.3,0.5,0.7)$ & $(0.3,0.5,0.7)$ &
\end{tabular}


Tablo 9. Normalleştirilmiş Bulanık Karar Matrisi

\begin{tabular}{|c|c|c|c|c|c|c|c|}
\hline & TK & $\mathrm{YM}$ & $\mathrm{T}$ & RP & GB & Ös & $\mathrm{ZS}$ \\
\hline ANITUR & $(0.6,0.8,1)$ & $(0.6,0.8,1)$ & $(0.3,0.5,0.7)$ & $(0.3,0.5,0.7)$ & $(0,0.2,0.4)$ & $(0.3,0.5,0.7)$ & $(0.3,0.5,0.7)$ \\
\hline JOLLYTUR & $(0.8$, & $(0.8,1,1)$ & $(0.6,0.8,1)$ & $(0.6,0.8,1)$ & $(0.6,0.8,1)$ & $(0.8,1,1)$ & $(0.6,0.8,1)$ \\
\hline ETSTUR & $(0.8,1,1)$ & $(0.8,1,1)$ & $(0.8,1,1)$ & $(0.8,1,1)$ & $(0.6,0.8,1)$ & $(0.8,1,1)$ & $(0.6,0.8,1)$ \\
\hline \multirow[t]{2}{*}{ TATÍL.COM } & $(0.6,0.8,1)$ & $(0.8,1,1)$ & $(0,0.2,0.4)$ & $(0.3,0.5,0.7)$ & $(0.3,0.5,0.7)$ & $(0.8,1,1)$ & $(0.3,0.5,0.7)$ \\
\hline & GÜ & SE & AS & ÖN & GMS & $\mathrm{KGS}$ & \\
\hline ANITUR & $(0.3,0.5,0.7)$ & $(0,0.2857,0.5714)$ & $(0.3,0.5,0.7)$ & $(0.3,0.5,0.7)$ & $(0.3,0.5,0.7)$ & $(0.3,0.5,0.7)$ & \\
\hline JOLLYTUR & $(0.8,1,1)$ & $(0.4286,0.7143,1)$ & $(0.3,0.5,0.7)$ & $(0.8,1,1)$ & $(0.3,0.5,0.7)$ & $(0.8,1,1)$ & \\
\hline ETSTUR & $(0.8,1,1)$ & $(0.4286,0.7143,1)$ & $(0.8,1,1)$ & $(0.8,1,1)$ & $(0.8,1,1)$ & $(0.8,1,1)$ & \\
\hline TATİL.COM & $(0.6,0.8,1)$ & $(0,0.2857,0.5714)$ & $(0.3,0.5,0.7)$ & $(0.3,0.5,0.7)$ & $(0.3,0.5,0.7)$ & $(0.3,0.5,0.7)$ & \\
\hline
\end{tabular}

Adım 4: Ağırlıklandırılmış normalize edilmiş bulanık karar matrisinin oluşturulması: Ağırlıklandırılmış normalize edilmiş bulanık karar matrisi AHP yöntemi ile elde edilen ağırlıklarla normalize edilmiş bulanık karar matrisinin çarpımı ile (Eşitlik 9) elde edilir. Ağırlıklandırılmış normalize edilmiş bulanık karar matrisi Tablo 10'da görülmektedir.

Tablo 10. Ağırıklandırılmış Normalize Edilmiş Bulanık Karar Matrisi

\begin{tabular}{|c|c|c|c|c|c|c|c|}
\hline & TK & YM & $\mathrm{T}$ & RP & GB & Ös & $\mathrm{ZS}$ \\
\hline $\begin{array}{l}\text { ANI } \\
\text { TUR }\end{array}$ & $\begin{array}{c}(0.0078, \\
0.0104, \\
0.0130)\end{array}$ & $\begin{array}{c}0.0114, \\
0.0152, \\
0.0190)\end{array}$ & $\begin{array}{c}0.0084, \\
0.0140, \\
0.0196)\end{array}$ & $\begin{array}{c}0.0105, \\
0.0175, \\
0.0245)\end{array}$ & $\begin{array}{c}(0, \\
0.0106, \\
0.0212)\end{array}$ & $\begin{array}{c}0.0282, \\
0.0470, \\
0.0658)\end{array}$ & $\begin{array}{c}(0.0303, \\
0.0505, \\
0.0707)\end{array}$ \\
\hline $\begin{array}{c}\text { JOLLY } \\
\text { TUR }\end{array}$ & $\begin{array}{c}0.0104, \\
0.0130, \\
0.0130)\end{array}$ & $\begin{array}{c}0.0152, \\
0.0190, \\
0.0190)\end{array}$ & $\begin{array}{c}0.0168, \\
0.0224, \\
0.0280)\end{array}$ & $\begin{array}{c}0.0210, \\
0.0280, \\
0.0350)\end{array}$ & $\begin{array}{c}0.0318, \\
0.0424, \\
0.0530)\end{array}$ & $\begin{array}{c}0.0752, \\
0.0940, \\
0.0940)\end{array}$ & $\begin{array}{c}0.0606, \\
0.0808, \\
0.1010)\end{array}$ \\
\hline $\begin{array}{l}\text { ETS } \\
\text { TUR }\end{array}$ & $\begin{array}{c}(0.0104, \\
0.0130, \\
0.0130)\end{array}$ & $\begin{array}{c}(0.0152, \\
0.0190, \\
0.0190)\end{array}$ & $\begin{array}{l}(0.0224, \\
0.0280, \\
0.0280)\end{array}$ & $\begin{array}{c}(0.0280, \\
0.0350, \\
0.0350)\end{array}$ & $\begin{array}{c}(0.0318, \\
0.0424, \\
0.0530)\end{array}$ & $\begin{array}{c}(0.0752, \\
0.0940, \\
0.0940)\end{array}$ & $\begin{array}{c}(0.0606, \\
0.0808, \\
0.1010)\end{array}$ \\
\hline $\begin{array}{c}\text { TATİL. } \\
\text { COM }\end{array}$ & $\begin{array}{c}(0.0078, \\
0.0104, \\
0.0130)\end{array}$ & $\begin{array}{c}(0.0152, \\
0.0190, \\
0.0190)\end{array}$ & $\begin{array}{c}(0, \\
0.0056, \\
0.0112)\end{array}$ & $\begin{array}{l}(0.0105, \\
0.0175, \\
0.0245)\end{array}$ & $\begin{array}{c}(0.0159, \\
0.0265, \\
0.0371)\end{array}$ & $\begin{array}{c}(0.0752, \\
0.0940, \\
0.0940)\end{array}$ & $\begin{array}{c}(0.0303, \\
0.0505, \\
0.0707)\end{array}$ \\
\hline & GÜ & SE & AS & ÖN & GMS & KGS & \\
\hline $\begin{array}{l}\text { ANI } \\
\text { TUR }\end{array}$ & $\begin{array}{c}0.0564, \\
0.0940, \\
0.1316)\end{array}$ & $\begin{array}{c}(0, \\
0.0983, \\
0.1966) \\
\end{array}$ & $\begin{array}{c}0.0015, \\
0.0025, \\
0.0035)\end{array}$ & $\begin{array}{c}0.0030, \\
0.0050, \\
0.0070)\end{array}$ & $\begin{array}{c}0.0069, \\
0.0115, \\
0.0161) \\
\end{array}$ & $\begin{array}{c}0.0261, \\
0.0435, \\
0.0609)\end{array}$ & \\
\hline $\begin{array}{c}\text { JOLLY } \\
\text { TUR }\end{array}$ & $\begin{array}{c}(0.1504, \\
0.1880, \\
0.1880)\end{array}$ & $\begin{array}{c}0.1474, \\
0.2457, \\
0.3440)\end{array}$ & $\begin{array}{l}(0.0015, \\
0.0025, \\
0.0035)\end{array}$ & $\begin{array}{c}0.0080, \\
0.0100, \\
0.0100)\end{array}$ & $\begin{array}{c}(0.0069, \\
0.0115, \\
0.0161)\end{array}$ & $\begin{array}{c}(0.0696, \\
0.0870, \\
0.0870)\end{array}$ & \\
\hline $\begin{array}{l}\text { ETS } \\
\text { TUR }\end{array}$ & $\begin{array}{c}0.1504, \\
0.1880, \\
0.1880)\end{array}$ & $\begin{array}{c}0.1474, \\
0.2457, \\
0.3440)\end{array}$ & $\begin{array}{c}(0.0040, \\
0.0050, \\
0.0050)\end{array}$ & $\begin{array}{c}(0.0080, \\
0.0100, \\
0.0100)\end{array}$ & $\begin{array}{c}0.0184, \\
0.0230, \\
0.0230)\end{array}$ & $\begin{array}{c}0.0696, \\
0.0870, \\
0.0870)\end{array}$ & \\
\hline $\begin{array}{c}\text { TATİL. } \\
\text { COM }\end{array}$ & $\begin{array}{c}0.1128, \\
0.1504, \\
0.1880)\end{array}$ & $\begin{array}{c}(0, \\
0.0983, \\
0.1966)\end{array}$ & $\begin{array}{c}0.0015, \\
0.0025, \\
0.0035)\end{array}$ & $\begin{array}{c}(0.0030, \\
0.0050, \\
0.0070)\end{array}$ & $\begin{array}{c}(0.0069, \\
0.0115, \\
0.0161)\end{array}$ & $\begin{array}{c}(0.0261, \\
0.0435, \\
0.0609)\end{array}$ & \\
\hline
\end{tabular}

Adım 5: Bulanık pozitif (BPIÇ. $\left.A^{*}\right)$ ve bulanık negatif ideal çözümlerin (BNIÇ.A-) belirlenmesi: Bulanık pozitif (BPIÇ. A*) ve bulanık negatif ideal çözümlerin (BNIÇ.A') belirlenirken ağırlıklandırılmış normalize edilmiş matristeki her bir kriter ayrı ayrı değerlendirilerek tüm alternatifler içindeki maksimum değer
(Eşitlik 10) bulanık pozitif ideal çözüm (BPIÇ. A*) olurken yine kriter bazında tüm alternatifler içindeki minumum değer (Eşitlik 11) bulanık negatif ideal çözüm (BNIÇ.A') olur. Bu bağlamda Tablo 11'de her bir kriter için BPIÇ. $A^{*}$ ve BNIÇ.A değerleri verilmiştir. 
Tablo 11. BPIÇ. A*ve BNIÇ.A' Değerleri

\begin{tabular}{|c|c|c|}
\hline Kriterler & $\mathrm{A}^{*}$ & $\mathrm{~A}^{-}$ \\
\hline TK & $(0.013,0.013,0.013)$ & $(0.0078,0.0078,0.0078)$ \\
\hline YM & $(0.019,0.019,0.019)$ & $(0.0114,0.0114,0.0114)$ \\
\hline T & $(0.028,0.028,0.028)$ & $(0.0,0.0,0.0)$ \\
\hline RP & $(0.035,0.035,0.035)$ & $(0.0105,0.0105,0.0105)$ \\
\hline GB & $(0.053,0.053,0.053)$ & $(0.0,0.0,0.0)$ \\
\hline ÖS & $(0.094,0.094,0.094)$ & $(0.0282,0.0282,0.0282)$ \\
\hline ZS & $(0.101,0.101,0.101)$ & $(0.0303,0.0303,0.0303)$ \\
\hline GÜ & $(0.188,0.188,0.188)$ & $(0.0564,0.0564,0.0564)$ \\
\hline SE & $(0.344,0.344,0.344)$ & $(0.0,0.0,0.0)$ \\
\hline AS & $(0.005,0.005,0.005)$ & $(0.0015,0.0015,0.0015)$ \\
\hline ON & $(0.01,0.001,0.01)$ & $(0.003,0.003,0.003)$ \\
\hline GMS & $(0.023,0.023,0.023)$ & $(0.0069,0.0069,0.0069)$ \\
\hline KGS & $(0.087,0.087,0.087)$ & $(0.0261,0.0261,0.0261)$ \\
\hline
\end{tabular}

Adım 6: Bulanık ideal çözümlerin uzaklıklarının hesaplanmasi: Alternatiflerin bulanık pozitif ve bulanık negatif ideal çözüme uzaklıkları eşitlik 14’e göre yapılmıştır. Örneğin ikinci alternatifin bulanık pozitif ideal çözüme uzaklığının $\left(d_{2}^{*}\right)$ ve bulanık negatif ideal çözüme uzaklığının $\left(d_{2}^{-}\right)$hesaplanışı aşağıda verilmiştir. Her bir alternatifin tüm kriterlere göre BPIÇ. A*den uzaklıkları Tablo 12.de ve BNIÇ.A'den uzaklıkları Tablo 13'de verilmiştir.

$$
\begin{aligned}
& d_{2}^{*}=\sqrt{\frac{1}{3}\left[(0.013-0.0078)^{2}+(0.013-0.0104)^{2}+(0.013-0.013)^{2}\right]} \\
& d_{2}^{*}=0.0015 \\
& d_{1}^{-}=\sqrt{\left[(0.0078-0.0104)^{2}+(0.0078-0.013)^{2}+(0.0078-0.013)^{2}\right]} \\
& d_{2}^{-}=0.0045
\end{aligned}
$$

Tablo 12. Alternatiflerin Her Bir Kriter Bazında Bulanık Pozitif İeal Çözüme (BPIÇ. A*) Uzaklıkları

\begin{tabular}{|c|c|c|c|c|}
\hline Kriterler & $\mathrm{d}\left(\mathrm{A}_{1} \cdot \mathrm{A}^{*}\right)$ & $\mathrm{d}\left(\mathbf{A}_{2} \cdot \mathrm{A}^{*}\right)$ & $\mathrm{d}\left(\mathbf{A}_{3} \cdot \mathbf{A}^{*}\right)$ & $\mathrm{d}_{\left(\mathbf{A}_{4} \cdot \mathbf{A}^{*}\right)}$ \\
\hline TK & 0.0034 & 0.0015 & 0.0015 & 0.0034 \\
\hline YM & 0.0049 & 0.0022 & 0.0022 & 0.0022 \\
\hline T & 0.0147 & 0.0072 & 0.0032 & 0.0229 \\
\hline RP & 0.0184 & 0.0090 & 0.0040 & 0.0184 \\
\hline GB & 0.0433 & 0.0137 & 0.0137 & 0.0279 \\
\hline OS & 0.0494 & 0.0109 & 0.0109 & 0.0109 \\
\hline ZS & 0.0531 & 0.0261 & 0.0261 & 0.0531 \\
\hline GÜ & 0.0989 & 0.0217 & 0.0217 & 0.0485 \\
\hline SE & 0.2585 & 0.1269 & 0.1269 & 0.2585 \\
\hline AS & 0.0026 & 0.0026 & 0.0006 & 0.0026 \\
\hline ON & 0.0053 & 0.0012 & 0.0012 & 0.0053 \\
\hline GMS & 0.0121 & 0.0121 & 0.0027 & 0.0121 \\
\hline KGS & 0.0458 & 0.0100 & 0.0100 & 0.0458 \\
\hline
\end{tabular}

Tablo 13. Alternatiflerin Her Bir Kriter Bazında Bulanık Negatif İdeal Çözüme (BNIÇ.A) Uzaklıkları

\begin{tabular}{|c|c|c|c|c|}
\hline Kriterler & $\mathrm{d}\left(\mathrm{A}_{1} \cdot \mathrm{A}^{-}\right)$ & $\mathrm{d}\left(\mathrm{A}_{2} \cdot \mathrm{A}^{-}\right)$ & $\mathrm{d}\left(\mathrm{A}_{3} \cdot \mathrm{A}^{-}\right)$ & $\mathrm{d}\left(\mathrm{A}_{4} \cdot \mathrm{A}^{-}\right)$ \\
\hline TK & 0.0034 & 0.0045 & 0.0045 & 0.0034 \\
\hline YM & 0.0049 & 0.0066 & 0.0066 & 0.0066 \\
\hline T & 0.0147 & 0.0229 & 0.0263 & 0.0072 \\
\hline RP & 0.0090 & 0.0184 & 0.0224 & 0.0090 \\
\hline GB & 0.0137 & 0.0433 & 0.0433 & 0.0279 \\
\hline OS & 0.0494 & 0.0882 & 0.0882 & 0.0882 \\
\hline ZS & 0.0261 & 0.0531 & 0.0531 & 0.0261 \\
\hline GÜ & 0.0485 & 0.1204 & 0.1204 & 0.0989 \\
\hline SE & 0.1269 & 0.2585 & 0.2585 & 0.1269 \\
\hline AS & 0.0013 & 0.0013 & 0.0032 & 0.0013 \\
\hline ON & 0.0026 & 0.0064 & 0.0064 & 0.0026 \\
\hline GMS & 0.0059 & 0.0059 & 0.0147 & 0.0059 \\
\hline KGS & 0.0225 & 0.0557 & 0.0557 & 0.0225 \\
\hline
\end{tabular}

Adım 7: Alternatiflerin bulanık pozitif ve bulanık negatif ideal çözüme uzaklık toplamlarının hesaplanması : Bu toplam Tablo 14.te verilmiştir.

Tablo 14. Alternatiflerin $d_{i}^{*}$ ve $d_{i}$ Değerleri

\begin{tabular}{|c|c|c|}
\hline Alternatifler & $\mathbf{d}_{\mathrm{i}}{ }{ }$ (BPIÇ) & $\mathbf{d}_{\mathrm{i}}{ }^{\circ}$ (BNIÇ) \\
\hline $\mathbf{A}_{1}$ & 0.6104 & 0.3289 \\
\hline $\mathrm{A}_{2}$ & 0.2451 & 0.6851 \\
\hline $\mathrm{A}_{3}$ & 0.2246 & 0.7032 \\
\hline $\mathrm{A}_{4}$ & 0.5115 & 0.4264 \\
\hline
\end{tabular}

Adım 8: Yakınlık katsayılarının $\left(C_{i}\right)$ hesaplanmasi: Yakınlık katsayıları (CC) hesaplanırken eşitlik 15 kullanılır. Örneğin birinci alternatifin yakınlık katsay1sı $\left(\mathrm{CC}_{1}\right)$ şöyle hesaplanır:

$\mathrm{CC}_{1}=\mathrm{d}_{\mathrm{i}} /\left(\mathrm{d}_{\mathrm{i}}+\mathrm{d}_{\mathrm{i}}\right)=0.3289 /(0.3289+0.6104)=0.3502$ olarak hesaplanir.

Diğer alternatifler için $\mathrm{CC}_{\mathrm{i}}$ değerleri Tablo 15.de verilmektedir.

\section{Tablo 15. Alternatifler İçin Yakınlık Katsayısı} (CC) ve Siralaması

\begin{tabular}{|c|c|c|}
\hline Alternatifler & $\left(\mathbf{C C}_{\mathbf{i}}\right)$ & SIRALAMA \\
\hline $\mathbf{A}_{1}$ & 0.3502 & 4 \\
\hline $\mathbf{A}_{2}$ & 0.7365 & 2 \\
\hline $\mathbf{A}_{3}$ & 0.7579 & 1 \\
\hline $\mathbf{A}_{4}$ & 0.4546 & 3 \\
\hline
\end{tabular}


Alternatiflerin yakınlık katsayısı $\left(\mathrm{CC}_{i}\right)$ değerlerine göre sıralaması şöyledir: $A_{3}>A_{2}>A_{4}>A_{1}$ olarak bulunmuştur.

Tablo 4.e göre alternatiflerin yakınlık katsayılarına $\left(\mathrm{CC}_{\mathrm{i}}\right)$ göre kabul koşulları $\mathrm{A}_{1}$ "alternatifi yüksek risk ile tavsiye edilir", $\mathrm{A}_{2}$ ve $\mathrm{A}_{3}$ alternatifleri "kabul edilir" ve $\mathrm{A}_{4}$ "düşük risk ile tavsiye edilir” şeklinde değerlendirilebilir.

\section{Sonuç ve Değerlendirme}

Günümüz dünyasında hızlı gelişen teknolojiyle birlikte yoğun bir iş temposu ortaya çıkmıştır. İnsanlar bu yoğun iş temposundan uzaklaşmak için tatil ihtiyacı duymaktadır. Bunu firsat bilen tur operatörleri hazırladıkları cazip tatil teklifleriyle müşterilerin ilgisini çekmeye çalışmakta ve bunun için otellerle anlaşma yaparak sürekliliklerini sağlamaktadır. Otellerde tur operatörleriyle anlaşma yaparken birçok kriteri göz önünde bulundurarak kalitelerini korumaktadırlar.

Bu çalışmada da AHP ve Bulanık TOPSIS yöntemi birlikte kullanılarak otellerin anlaşma yapacağ $\mathrm{en}$ iyi tur operatörü alternatifi belirlenmiştir. Tur operatörü seçiminde otele yönelik ve tur operatörüne yönelik kriterler belirlenerek Isparta ilinde faaliyette bulunan beş yıldızlı otel ile yapılan görüşme sonucunda, araştırmada belirlenen alternatiflerden Jolly Tur ve ETS Tur sermaye, güvenilirlilik ve zorunlu hizmet sigortası kriterleri açısından en yüksek değerleri almıştır. Sonuç olarak ETS Tur ve Jolly Tur kabul edilebilir bir değerle ilk iki sırayı alırken ETS Tur küçük bir farkla da olsa ilk sırada yer almaktadır. Tatil.com ise düşük riskle üçüncü sırada yer almıştır. Çalışmada kullanılan kriterler ve yöntem benzer konseptte çalışan diğer otellerin de kullanabileceği, uygulayabileceği ve sonuç alabileceği yöntemlerdir. Çalışmanın turizm sektöründe faaliyette bulunan ve tur operatörleriyle çalışan işletmelere tur operatörü seçiminde yardımcı olacağı düşünülmektedir.

\section{Kaynakça}

Abalı Y.A., Kutlu B.S., Eren T., (2012). Çok Ölçütlü Karar Verme Yöntemleri ile Bursiyer Seçimi: Bir Ö ̆̆retim Kurumunda Uygulama", Atatürk Üniversitesi İktisadi ve İdari Bilimler Dergisi, 26, (3-4), 259-272.

Alaeddinoğlu F., Can A.S., (2007). Türk Turizm Sektöründe Tur Operatörleri ve Seyahat Acenteleri, Ticaret ve Turizm Eğitim Fakültesi Dergisi, 2, 50-66.
Alphonce C.B., (1997). Application of The Analytic Hierarchy Process in Agriculture in Developing Countries, Agricultural Systems, 53, (1), 97-112.

Amiri M.P., (2010). Project Selection For Oil-Fields Development By Using The AHP And Fuzzy TOPSIS Methods, Expert Systems with Applications, 37, (9), 6218-6224.

Awasthi A., Chauhan S.S., (2012). A Hybrid Approach Integrating Affinity Diagram, AHP And Fuzzy TOPSIS For Sustainable City Logistics Planning", Applied Mathematical Modelling, 36, (2), 573-584.

Başkaya Z., Akar C., (2005). Ürün Alternatifi Seçiminde Analitik Hiyerarşi Süreci: Tekstil İşletmesi Örneği, Anadolu Üniversitesi, Sosyal Bilimler Dergisi, 5, (1), 273-286.

Baykal N., Beyan T., (2004). Bulanık Mantık İlke ve Temelleri. Ankara:Bıçaklar.

Benı'tez J.M., Martı'n J.C., Roma'n C., (2007). Using Fuzzy Number for Measuring Quality of Service in The Hotel Industry", Tourism Management, 28, 544-555.

Bevilacqua M., Braglia M., (2000). The Analytic Hierarchy Process Applied to Maintenance Strategy Selection, Reliabillity Engineering and System Safety, 70, 71-83.

Boran F.E., Genc S., Kurt M., Akay D., (2009). A MultiCriteria Intuitionistic Fuzzy Group Decision Making For Supplier Selection With TOPSIS Method, Expert Systems with Applications, 36, (8), 11363-11368.

Chandran B., Golden B., Wasil E., (2005). Linear Programming Models For Estimating Weights in The Analytic Hierarchy Process, Computers \& Operations Research, 32, (9), 2235-2254.

Chang T.H., Wang T.C., (2009). Using The Fuzzy Multi-Criteria Decision Making Approach For Measuring The Possibility Of Successful Knowledge Management, Information Sciences, 179, (4), 355-370.

Chen C.T., (2000). Extensions of The TOPSIS for Group Decision-Making Under Fuzzy Environment, Fuzzy Sets and Systems, 114, 1-9.

Chen C.T., Lin C.T., Huang S.F., (2006). A Fuzzy Approach For Supplier Evaluation And Selection In Supply Chain Management", Int. J. Production Economics, 102, 289-301. 
Dağdeviren M., Yavuz S., Kılınc N., (2009). Weapon Selection Using The AHP And TOPSIS Methods Under Fuzzy Environment", Expert Systems with Applications, 36, (4), 8143-8151.

Demireli E., (2010). TOPSIS Çok Kriterli Karar Verme Sistemi: Türkiyedeki Kamu Bankaları Üzerine Bir Uygulama, Girişimcilik ve Kalkınma Dergisi, 5, (1), 101-112.

Doğan B., (2004). Karar Vermede Çok Kriterli Bir Yaklaşım Modeli Olarak Analitik Hiyerarşi Süreci Ve Mayın Avlama Gemisi Seçiminde Analitik Hiyerarşi Süreci yönteminin Uygulanması, (Yayınlanmamış Yüksek Lisans Tezi). Deniz Harp Okulu Deniz Bilimleri ve Mühendisliği Enstitüsü, İstanbul.

Ecer F., (2006). Bulanık Ortamlarda Grup Kararı Vermeye Yardımcı Bir Yöntem: Fuzzy TOPSIS Ve Bir Uygulama, Dokuz Eylül Üniversitesi, İsletme Fakültesi Dergisi, 7, (2), 77-96.

Eleren A, (2007). Markaların Tüketici Tercih Kriterlerine Göre Analitik Hiyerarşi Süreci Yöntemi ile Değerlendirilmesi: Beyaz Eşya Sektöründe Bir Uygulama, Celal Bayar Üniversitesi Yönetim ve Ekonomi Dergisi, 14, (2), 47-64.

Emir O., (2010). Otel İşletmelerinin Pazarlanmasında Seyahat Acentalarının Rolü: Otel İşletmeleri Tarafından Bir Değerlendirme, Ege Akademik Bakış, 10, (4), 1245-1256.

Erginel N., Çakmak T., Şentürk S., (2010). Numara Taşınabilirliği Uygulaması Sonrası Türkiye’de GSM Operatör Tercihlerinin Bulanık TOPSIS Yaklaşımı İle Belirlenmesi, Anadolu Üniversitesi Bilim Ve Teknoloji Dergisi, 11, (2), 81-93.

Eroğlu E., Lorcu F., (2007). Veri Zarflama Analitik Hiyerarşi Prosesi (VZAHP) İle Sayısal Karar Verme, İstanbul Üniversitesi İşletme Fakültesi İşletme Dergisi, 36, (2), 30-53.

Gökdeniz A., (1990). Paket Turlar ve Üretim Safhaları, Anatolia Aylık Turizm ve Kültür Sanat Dergisi, 6, (1), 44-48.

Güner M., (2003). Analitik Hiyerarşi Yönteminin Fason İşletme Seçiminde Kullanılması, Tekstil ve Konfeksiyon Dergisi, 4, 1-5.

Güner M., Yücel Ö., (2007). Konfeksiyon Üretiminde Temel Kriterlerin Hiyerarşik Modellenmesi İle Üretilecek En Uygun Ürünün Belirlenmesi, Gazi Üniversitesi, Mühendislik Mimarlık Fakültesi Dergisi, 22, (1), 73-79.
Huang J.H., Peng K.H., (2012). Fuzzy Rasch Model In TOPSIS: A New Approach For Generating Fuzzy Numbers to Assess The Competitiveness of The Tourism Industries in Asian Countries, Tourism Management, 33, (2), 456-465.

Hwang H.S., Moon C., Chuang C.L., Goan M.J., (2005). Supplier Selection Planning Model Using AHP, International Journal of The Systems for Logistics and Management, 1, (1), 47-53.

Ignatius J., Mustafa A., Goh M., (2012). Modeling Funding Allocation Problems Via Ahp-Fuzzy TOPSIS, International Journal of Innovative Computing, Information and Control, 8, (5-A), 3329-3340.

Kannan G., Pokharel S., Kumar P.S., (2009). A Hybrid Approach Using ISM And Fuzzy TOPSIS For The Selection Of Reverse Logistics Provider, Resources, Conservation and Recycling, 54, 28-36.

Karagül A.A., Özdemir A., (2010). Finansal Bilgi Kalitesinin Analitik Hiyerarşi Süreci Tekniğiyle Değerlendirilmesi: Bankacılık Sektörü Uygulaması, Anadolu Üniversitesi Sosyal Bilimler Dergisi, 10, (3), 43-58.

Kulak O., Durmusoğlu M.B., Kahraman C., (2005). Fuzzy Multi-Attribute Equipment Selection Based on Information Axiom, Journal of Materials Processing Technology, 169, (3), 337-345.

Kuruüzüm A., Atsan N., (2001). Analitik Hiyerarşi Yöntemi ve İşletmecilik Alanındaki Uygulamaları, Akdeniz Üniversitesi İktisadi ve İdari Bilimler Fakültesi Dergisi, 1, (1), 83-105.

Küçük O., Ecer F., (2007). Bulanık TOPSIS Kullanılarak Tedarikçilerin Değerlendirilmesi Ve Erzurum'da Bir Uygulama, Abant İzzet Baysal Üniversitesi İktisadi ve İdari Bilimler Fakültesi Ekonomik ve Sosyal Araştırmalar Dergisi, 3, (1), 45-65.

Maden U., (2007). Seçilmiş Özel Ticari Bankalarda Analitik Hiyerarşi Süreci Yöntemiyle Müssteri Bağhlığının Araştırılması. (Yayınlanmamış Yüksek Lisans Tezi). Gazi Üniversitesi/Sosyal Bilimler Enstitüsü, Ankara.

Mahmoodzadeh S., Shahrabi J., Pariazar M., Zaeri M.S., (2007). Project Selection by Using Fuzzy AHP and TOPSIS Technique, International Journal of Humanities and Social Sciences, 1, (3), 135-140.

Maniyaa K.D., Bhatt M.G., (2011). A Multi-Attribute Selection of Automated Guided Vehicle Using The AHP/M-GRA Tecnique, International Journal of Production Research, 49, (20), 6107-6124. 
MEB, (2007a). Konaklama Ve Seyahat Hizmetleri Turizm İșletmeleri, Mesleki Ĕ̆itim ve Öğretim Sisteminin Güçlendirilmesi Projesi, Ankara: http://hbogm. meb.gov.tr/modulerprogramlar/kursprogramlari/ konaklama/moduller/TurizmIsletmeleri.pdf

MEB, (2007b). Konaklama Ve Seyahat Hizmetleri Paket Tur Üretimi, Mesleki Eğitim Ve Öğretim Sisteminin Güçlendirilmesi Projesi, Ankara: http://hbogm. meb.gov.tr/modulerprogramlar/kursprogramlari/ konaklama/moduller/PaketTurUretimi.pdf

Önüt S., Soner S., (2008). Transshipment Site Selection Using The AHP And TOPSIS Approaches Under Fuzzy Environment, Waste Management, 28, (9), 1552-1559.

Özçakar N., Demir H., (2011). Bulanık TOPSIS Yöntemiyle Tedarikçi Seçimi, Yönetim (İstanbul Üniversitesi İşletme Fakültesi İsletme İktisadı Enstitüsü Dergisi), 22, (69), 25-44.

Özgüven N., (2011). Vakıf Üniversite Tercihinin Analitik Hiyerarşi Yöntemiyle Belirlenmesi, Dumlupınar Üniversitesi, Sosyal Bilimler Dergisi, 30, 279-290.

Phua M.H., Minowa M., (2005). A GIS-Based Multi-Criteria Decision Making Approach To Forest Conservation Planning At A Landscape Scale: A Case Study In The Kinabalu Area, Sabah, Malaysia, Landscape and Urban Planning, 71, 207-222.

Saat M., (2000). Çok Amaçlı Karar Vermede Bir Yaklaşım: Analitik Hiyerarşi Yöntemi, Gazi Üniversitesi İktisadi İdari Bilimler Fakültesi Dergisi, 2, (2), 149-162.

Saaty T.L. Vargas L.G., (2001). Models, Methods, Concepts \& Applications of The Analytic Hierarchy Process, Massachusetts:Kluwer Academic.

Saaty T.L., (1990). How To Make A Decision: The Analytic Hierarchy Prosess, Europan Journal of Operation Research, 48, 9-26.

Saaty T.L., (2008). Decision Making With The Analytic Hierarchy Process, International Journal Services Sciences, 1, (1), 83-98.

Saaty T.L., Tran L.T., (2007). On The Invalidity of Fuzzifying Numerical Judgments in The Analytic Hierarchy Process, Mathematical and Computer Modelling, 46, 962-975.

Salo A.A., Hamalainen R.P., (1997). On The Measurement of Preferences in The Analytic Hierarchy Process, Journal Of Multi-Criteria Decision Analysis, 6, (6), 309-319.
Shih H.S., Shyur H.J., Lee E.S., (2007). An Extension Of TOPSIS For Group Decision Making, Mathematical and Computer Modelling, 45, (7-8), 801-813.

Supçiller A.A., Çapraz O., (2011). AHP-TOPSIS Yönetimine Dayalı Tedarikçi Seçimi Uygulaması, Istanbul Üniversitesi İktisat Fakültesi Ekonometri ve İstatistik Dergisi, 13, 1-22.

Timor M., (2004). Şehiriçi Alışveriş Merkezi Yer Seçimi Faktörlerinin AHP Yardımıyla Sıralanması, Yönetim Dergisi, 15, (48), 3-18.

Timor M., (2011). Analitik Hiyerarşi Prosesi. İstanbul:Türkmen.

Uygurtürk H., Korkmaz T., (2012). Finansal Performansın TOPSIS Çok Kriterli Karar Verme Yöntemi İle Belirlenmesi: Ana Metal Sanayi İşletmeleri Üzerine Bir Uygulama, Eskişehir Osmangazi Üniversitesi İIBF Dergisi, 7, (2), 95-115.

Üner M., Sökmen A., Birkan İ., (2006). Türkiye’de Her Şey Dahil Uygulamasının Konaklama İşletmeleri Üzerindeki Etkisi: Antalya Örneği, Anatolia: Turizm Araștırmaları Dergisi, 17, (1), 35-50.

Wang J.W., Cheng C.H., Cheng H.K., (2009). Fuzzy Hierarchical TOPSIS For Supplier Selection, Applied Soft Computing, 9, (1), 377-386.

Wang T.C., Chang T.H., (2007). Application of TOPSIS in Evaluating Initial Training Aircraft Under A Fuzzy Environment, Expert Systems with Applications, 33, (7), 870-880.

Wang T.C., Lee H.D., Wu C.C., (2007). A Fuzzy TOPSIS Approach with Subjective Weights and Objective Weights, Proceedings of the $6^{\text {th }}$ WSEAS International Conference on Applied Computer Science, April 15-17, China, 1-6.

Wind Y., Saaty T.L., (1980). Marketing Applications of The Analytic Hierarchy Process, Management Science, 26, (7), 641-358.

Ylldız Z., (2011). Turizmin Sektörünün Gelişimi Ve İstihdam Üzerindeki Etkisi, Süleyman Demirel Üniversitesi Vizyoner Dergisi, 3, (5), 154-71.

Yurdakul M., İpek A.Ö., (2005). Malzeme Taşıma Sistemlerinin Seçilmesine Yönelik Bir Karar Destek Sistemi Geliştirilmesi, Gazi Üniversitesi Mühendislik Mimarlk Fakültesi Dergisi, 20, (2), 171-181.

Zadeh, L. A., (1965). Fuzzy Sets, Information and Control 8, 338-353. 